\title{
Earnings Management in Domestic and Foreign IPOs in the United States: Do Home Country Institutions Matter?
}

\author{
Igor Filatotchev \\ King's Business School \\ King's College London \\ Bush House \\ 30 Aldwych \\ London WC2B 4BG, UK \\ Email: Igor.Filatotchev@kcl.ac.uk \\ and \\ Vienna University of Economics and Business \\ Jonathan Jona* \\ Faculty of Business and Economics \\ The University of Melbourne \\ 198 Berkeley St. \\ 3010 Melbourne, Australia \\ Email: jonathan.jona@Unimelb.edu.au \\ Gilad Livne \\ University of Exeter Business School \\ Streatham Court, Rennes Drive \\ Exeter, EX4 2HE, UK \\ Email: g.livne@exeter.ac.uk
}

\begin{abstract}
April 2019
* Corresponding author. We thank two anonymous reviewers and Thomas Jean-Jean (the Editor), Dan Amiram, Mary Barth, Michael Dambra, Katerina Hellstrom, Amir Licht, Angela Pettinicchio, Matthew Pinnuck, Giulia Redigolo, Jay Ritter, Naomi Soderstrom, and Anne Wyatt. We also thank seminar participants at the BEROC Conference Minsk 2012, EAA Annual Meeting 2013, AAA Annual Meetings 2013 and 2015, Bocconi University, Cass Business School, ESSEC Paris, Griffith University, New Economic School, Oulu University, Stockholm School of Economics, Tsinghua University, University of Edinburgh Business School, University of Melbourne, University of New South Wales, University of Padua, University of Queensland, University of Southampton, University Technology Sydney, and Warwick Business School for their helpful comments on earlier versions of this paper.
\end{abstract}




\title{
Earnings Management in Domestic and Foreign IPOs in the United States: Do Home Country Institutions Matter?
}

\begin{abstract}
Using a large sample of domestic and foreign IPOs in the US, we investigate how threats of enforcement by the Securities and Exchange Commission (SEC) and private litigation influence earnings management in IPO prospectuses. We propose that perceptions of foreign institutions may influence SEC enforcement action and private litigation. We provide evidence that enforcement and litigation threats are negatively related to the strength of legal institutions in the foreign IPO's country of origin. We find earnings management is more pronounced in foreign IPOs from countries with strong legal institutions. We further explore whether earnings management is priced in the IPO market and find no relation between IPO proceeds and earnings management. Our results are consistent with upward earnings management as in Stein (1989), the magnitude of which is reduced when the anticipated cost of enforcement and litigation is higher. Collectively, our results cast doubt on the validity of the bonding hypothesis.
\end{abstract}

Keywords: Foreign IPOs; bonding; perceptions of foreign institutions, SEC enforcement; abnormal accruals;

JEL classification: G18; M41; M43; M44 


\section{Earnings Management in Domestic and Foreign IPOs in the United States: Do Home Country Institutions Matter?}

\section{Introduction}

Earnings management has attracted significant attention in prior research, as managers can use earnings to opportunistically influence various corporate outcomes such as security prices, debt contracts, and personal compensation. This research has mainly focused on corporate governance mechanisms that could mitigate the adverse effects associated with opportunistic earnings management, but has produced ambiguous results (Larcker, Richardson, \& Tuna, 2007). However, the incidence and magnitude of earnings management is not only a function of firm-specific corporate governance mechanisms, it also reflects a firm's exposure to external, macroinstitutional forces such as investor protection, enforcement risk, private litigation, and investor beliefs.

Securities laws offer a varying degree of investor protection across countries (La Porta, Lopezde-Silanes, Shleifer, \& Vishny, 2002). Such variety has been linked to differences in the extent of earnings management at the country-level, with the extent being higher in institutional environments with weaker investor protection (Bushman and Piotroski, 2006; Bushman, Piotroski, \& Smith, 2004; Leuz, Nanda, \& Wysocki, 2003). Moreover, the “bonding” hypothesis (Coffee, 1999; Stulz, 1999) posits that foreign firms can circumvent the effects of a weak corporate governance regime in their home countries through a commitment to better governance mechanisms by listing in countries with stronger legal institutions, such as the US. Arguably, bonding works insofar as it is backed by a credible threat of enforcement and litigation. However, bonding is less likely to work where foreign firms do not anticipate close scrutiny with associated adverse consequences. As we subsequently explain, it is plausible such threats are shaped by the

perceptions of the legal institutions of the foreign firm's country of origin. These perceptions are 
particularly salient in the US IPO market, because foreign IPOs are relatively unknown entities when entering US capital markets. In this paper we therefore examine the relation between earnings management in foreign IPOs and home institutions.

Prior research has not investigated whether foreign IPOs manage earnings at a similar level as domestic US IPOs, as the bonding hypothesis suggests. Most studies investigating the bonding hypothesis have used samples comprised primarily of cross-listed firms (i.e., firms with listings in both their home country and in the US) and report mixed results. ${ }^{1}$ However, the strength of bonding in cross-listed firms may differ substantially from that of IPOs for several reasons. First, crosslisted firms are typically more mature and, as such firms have been listed in the US for several years, they are better known to US investors. Being relatively unknown, IPO managers can exploit their information advantage by managing earnings more aggressively than mature firms. Second, cross-listed firms need to satisfy several sets of national securities regulations, which may compromise bonding to US rules. Third, while the IPO market may present stronger incentives to manipulate earnings than in the secondary market (Teoh, Welch, \& Wong, 1998), it is also characterized by a higher level of investor and regulatory scrutiny (Ball and Shivakumar, 2008; Ndubizu, 2007). However, prior literature has not examined if such scrutiny is equally applied to IPOs regardless of their country of origin.

Earnings management may vary in IPOs according to country of origin even though they exclusively list in the US. First, if the IPO's main activities remain located in its home country, relevant laws still likely govern a broad range of contracts in that country (e.g., compensation, CEO dismissals, borrowing and entering liquidation procedures). Extant research has shown that such contracts may motivate earnings management. ${ }^{2}$ Second, perceptions by US investors and

\footnotetext{
${ }^{1}$ See Karolyi (2012) for a review of the evidence on the bonding hypothesis.

${ }^{2}$ Our paper, however, does not provide evidence pertaining to the importance of contracting in an IPO's home country.
} 
government officials of foreign institutions likely play an important role. These parties may be suspicious of foreign firms-and foreign IPOs in particular-because of a lack of familiarity (Merton, 1987) and perceptions of institutional and cultural distance. ${ }^{3}$ Bearing in mind that the SEC's monitoring and enforcement resources are costly and limited (e.g., Correia, 2014; Kedia and Rajgopal, 2011), we argue that SEC is vulnerable to adverse political consequences of accounting irregularities (Bushman and Piotroski, 2006). We further posit that these consequences are more pronounced in the case of US domestic IPOs, because they are primarily owned by US investors. Thus, the SEC directs more enforcement resources to US domestic IPOs. Among foreign IPOs, the SEC is more likely to monitor and initiate disciplinary actions against—and investors may be more inclined to sue-those IPOs they perceive to have poor corporate governance based on country of origin (Gu, Filatotchev, Bell, \& Rasheed, 2018). Expecting this, foreign IPOs from countries with weak institutions would manage earnings to a lesser extent than IPOs from countries with strong institutions.

In our first set of analysis, we provide evidence supporting the conjecture that SEC enforcement and private litigation are directed relatively more at firms originating from countries with weak institutions. We then present evidence that earnings management is inversely related to the enforcement and litigation threats. In the second set of analysis, we explore the relation between home country institutions and earnings management. We find foreign IPOs from countries with strong institutions inflate earnings more than both domestic US IPOs and other foreign IPOs.

Our final analysis examines the pricing implications of earnings management. Because IPO firms raise cash, it is possible that the objective of earnings management is to inflate earnings to increase proceeds (Teoh et al., 1998; Teoh and Wong, 2002). This suggests a positive relation

\footnotetext{
${ }^{3}$ We elaborate on the role of perceptions in Section 2.3.
} 
between earnings management and IPO proceeds. On the other hand, Shivakumar (2000), building on Stein (1989), argued that since investors expect earnings management, the best response for managers is to increase earnings. In equilibrium, managers are "trapped" into managing earnings upward, but investors rationally discount earnings management. Consistent with this, we find no relation between earnings management and IPO proceeds.

We contribute to the IPO literature in five ways. First, Lang, Raedy, \& Wilson (2006) explored earnings quality in mature foreign firms listed in the US and found evidence suggestive of poorer earnings quality in cross-listed firms from countries with weak institutions. We show that in the IPO market, earnings management is more pronounced in IPOs from countries with strong institutions. Second, our results are relevant for assessing the strength of the bonding theory. Our evidence stands in contrast to the conclusions of several prior papers arguing that bonding works. Moreover, we provide evidence consistent with a link between SEC enforcement, or private litigation, and home institutions. This link is indicative of the role of perceptions when information asymmetry is high. Third, we add further evidence on how the SEC prioritizes its limited resources (e.g., Correia, 2014; Kedia and Rajgopal, 2011) and extend this line of research to the IPO market. Fourth, our evidence further supports the notion that reputational concerns may generate bonding (Siegel, 2005). In particular, IPOs from weak-institution countries use less-aggressive accounting, as would be expected from a motivation to build reputational capital. Finally, we extend Sivakumar's (2000) results obtained for seasoned equity offerings to the foreign IPO market by showing that earnings management is not priced. 


\section{Related Literature and Hypotheses Development}

\subsection{IPO Earnings Management}

Earnings management may be difficult to detect in IPOs because new firms are less known to market participants. Teoh and Wong (2002) provided evidence that analysts are insufficiently skeptical regarding IPO accruals management, whereas this is not the case for mature firms. This lack of familiarity may be more pronounced for foreign IPOs owing to the distance of their main operations from capital markets and US investors (Coval and Moskowitz, 1999; Malloy, 2005) and, more generally, owing to their foreignness.

Insofar as information asymmetry and lack of familiarity allow for more earnings management, earnings may be inflated by IPO owners seeking to maintain control and personal benefits (Leuz, et al., 2003). The evidence on earnings management in IPOs is, however, mixed. Ball and Shivakumar (2008) posited that pre-IPO accruals should be used to capture earnings management to influence IPO outcomes, implying measures of post-IPO accruals used by Teoh et al. (1998) are contaminated by the effect of IPO proceeds on abnormal accruals. Ball and Shivakumar (2008, p. 324) showed that pre-IPOs earnings are more conservative than mature firms' earnings and attribute this finding to "higher monitoring by auditors, boards, analysts, rating agencies, press, and litigants, and to greater regulatory scrutiny.” A similar result is reported in Venkataraman, Weber, \& Willenborg (2008), who attributed it to the 1933 Securities Act. This Act governs IPOs and provides investors with better legal protection than the 1934 Securities Exchange Act, which 
applies to the secondary market. ${ }^{4}$ In contrast, Aharony, Lin, \& Loeb (1993) did not find evidence of either earnings inflation or deflation in pre-IPO financials. ${ }^{5}$

\subsection{Bonding to US Institutions}

Foreign firms may decide to list in the US for several reasons including benefiting from highly liquid markets, a broader investor base, cheaper finance, and greater product and corporate visibility (Licht, 2003). Coffee (1999) and Stulz (1999) argued that a different set of benefitsrelated to corporate governance-plays an important role in the listing decision. Specifically, by listing in the US, foreign firms "rent" what many regard (but not all agree upon) to be the strongest global set of legal, enforcement, and disclosure mechanisms. As such, "renting” legal institutions helps these firms to credibly mitigate agency conflicts otherwise unavoidable in their home countries. However, as Coffee (2002) acknowledged, in the case of cross-listing (i.e., firms with US as well as home listings), foreign firms must also meet home-country rules and cannot exclusively obey US rules. He further argues that in order to completely escape home jurisdiction, a foreign firm should adopt an IPO route. Prior literature is silent on whether this conjecture is supported empirically. Amir, Harris, \& Venuti (1993) and Lang et al. (2006) provided evidence on earnings management consistent with mature cross-listed firms not fully bonding with US reporting standards. Silvers (2016) examined SEC enforcement actions against foreign firms listed in the US and found positive market reaction to such enforcement actions in mature foreign firms not targeted by the SEC. Silvers (2016) interpreted this result as supporting bonding; however, the

\footnotetext{
${ }^{4}$ Perhaps the most relevant section of the 1933 Act is Section 11. It stipulates that damages can arise when an investor relies on a prospectus and the award to the successful plaintiff is larger when the difference between the offer price and the sell price is greater, or the price at the time of the lawsuit. Lowry and Shu (2002) found the incidence of litigation against IPOs stands at about $6 \%$ and that most of the suits were brought under this section.

${ }^{5}$ Ndubizu (2007) found foreign IPOs manage earnings more than mature US firms. Lee and Masulis (2011) found IPOs select underwriters to reduce information asymmetry, which, in turn, reduces earnings management. However, both papers use post-IPO quarterly accruals. We control for underwriters' reputation in our robustness tests (see Section 5.2).
} 
cause of this effect may be due to lower expected litigation costs in non-target firms because the SEC has constrained resources (as we discuss below).

A number of legal scholars have challenged the bonding theory and its underlying assumptions. Licht (2000, 2003) argued the legal remedies available to shareholders of US-listed foreign firms are markedly weaker than those available to shareholders of domestic US firms. Moreover, for foreign firms, the SEC "cuts corners" on issues of corporate governance, evidence of which can be found in official pronouncements (e.g., NYSE, 2013). ${ }^{6}$ Shnitser (2010, p. 1644) further stated that "foreign issuers face minimal litigation exposure when cross-listing in the US." Cheng, Srinivasan, \& Yu (2014) showed the incidence of class action lawsuits against cross-listed firms is significantly lower than against US firms. Similar to Fanto (1996) and Siegel (2005), they posited that this is caused by greater challenges in obtaining relevant information from foreign firms in regard to litigation.

While the bonding hypothesis highlights the role of legal and enforcement mechanisms, several papers point to the possibility that commitment to high-quality reporting may take place even in the absence of formal rules or powerful regulators. Gomes (2000) explored a model in which insiders commit not to expropriate minority shareholders in order to establish a reputation for "good behavior." Insiders benefit from this strategy because it helps them obtain the highest price when selling their shares following the IPO. This literature implies that more conservative reporting can convey a commitment not to use earnings management to mask expropriation of minority shareholders.

It is well-known that the SEC has faced significant budget constraints (Cox, Thomas, \& Kiku, 2003; Stewart, 2011). Prior research suggests that SEC enforcement would first target US domestic

\footnotetext{
${ }^{6}$ This regulatory "lighter touch" is likely motivated by the desire to attract foreign listings to the US.
} 
firms, because of their proximity and cost-saving implications (Kedia and Rajgopal, 2011), as well as non-politically connected firms (Correia, 2014). Private investors may also find it is simpler to sue US managers because of the difficulties in dealing with firms headquartered in non-US jurisdictions (Cheng, et al., 2014). ${ }^{7}$ In addition, with a home bias in investment decisions (Coval and Moskowitz, 1999), the SEC may face political and media pressure if it fails to discipline US domestic IPOs first and foremost (Bushman and Piotroski, 2006), and then discipline foreign firms that are more adversely perceived by investors and the public.

To the extent that domestic US IPOs attract more scrutiny, foreign IPOs in the US anticipate lower enforcement and litigation threats than domestic US IPOs. We therefore expect the level of earnings management in US-based foreign IPOs to exceed that of domestic IPOs. Our first hypothesis, in null form, is as follows:

H1: Foreign firms with IPOs in the US market manage earnings to a greater extent than US firms with IPOs in the US market.

\subsection{Perceptions of Home Institutions}

Prior research has established that history and culture shape a country’s institutions (Greif, 1994), resulting in cross-country institutional differences. Institutional theorists have emphasized the importance of perceptions of economic actors in various institutional contexts (Scott, 1995). For example, investor perceptions of investment risk have been linked to the effect of institutional characteristics of the country of origin on the listing choice (Moore, Bell, Filatotchev, \& Rasheed, 2012; Sarkissian and Schill, 2003). For investors, geographical and cultural proximity appear to drive decisions in which firms to invest, whereby investors exhibit a home bias, as they prefer local firms over foreign firms (Coval and Moskowitz, 1999; Grinblatt and Keloharju, 2001). The home

\footnotetext{
${ }^{7}$ Consistent with this, Cheng et al. (2014) reported that foreign firms are sued at a rate of $2.16 \%$ whereas in a sample of matched US firms the rate is $4.10 \%$.
} 
bias literature has also suggested that perceptions of foreign firms are shaped by institutional and cultural distance (Anderson, Fedenia, Hirschey, \& Skiba, 2011).

The international business literature has termed this "aversion” to foreign firms as the liability of foreignness (e.g., Zaheer, 1995). Specifically, Zaheer (1995, p. 343) defined this liability as "all additional costs a firm operating in a market overseas incurs that a local firm would not incur.” 8 Nahata, Hazarika, \& Tandon (2014) argued that differences in institutions can be a major source of conflict between company insiders and outsiders, making it more costly for a foreign firm to attract investment. More specifically, in many cases, the IPO firm's operations remain in the home country, and disputes between shareholders and other stakeholders may need to be resolved outside the US, which complicates conflict resolution for US investors and increases the cost of capital for a foreign firm (Nahata, et al., 2014).

Institutional similarity also shapes trust, which in turn influences investors' actions in stock markets owing to a perception of investment risk (Guiso, Sapienza, \& Zingales, 2008, 2009). Prior research has argued a firm's home institutions matter in that economic agents in the host country are more suspicious of foreign firms from farther institutional distances (Anderson, et al., 2011; Xu and Shenkar, 2002). Consistent with these arguments, emerging research in management and international business has presented evidence of a valuation effect of investors' perception of a foreign IPO’s home country institutions (e.g., Bell, Filatotchev, \& Aguilera, 2014; Gu et al., 2018).

Our second hypothesis therefore concerns how earnings management varies with home country institutions. We argue that perceptions form a channel through which home institutions can shape IPO earnings management. IPOs originating from weak-institution countries expect to be

\footnotetext{
${ }^{8}$ Research in accounting has largely overlooked the role of perceptions in the IPO market. An exception to this is a recent study by Blankespoor, Hendricks, \& Miller (2017) that used an experimental research design to investigate the effect of perceptions on IPO pricing.
} 
scrutinized more by US investors and regulators ${ }^{9}$ and thus manage earnings to a lesser extent. In contrast, managers of IPOs originating from countries with strong home institutions face a smaller incentive to constrain earnings management. Our second hypothesis therefore is:

H2: Earnings management is higher in IPOs originating from countries with strong legal institutions than in IPOs originating from countries with weak legal institutions.

\section{Research Design and Sample}

\subsection{Measuring Abnormal Accruals in IPOs}

Our measure of discretionary accruals uses financial data from IPO prospectuses and is based on Ball and Shivakumar (2008) for a number of reasons. First, the information in a prospectus is subject to more intense scrutiny by, for example, the SEC, ${ }^{10}$ underwriters, and in particular, auditors (Venkataraman, et al., 2008). Second, in an IPO context, reporting choices could be directed at influencing the amount of cash proceeds insiders hope to raise, or the subsequent market price. Post-IPO earnings obviously cannot be used for this purpose. Finally, using pre-IPO abnormal accruals is also warranted from a more technical perspective, as post-IPO accruals are likely affected by use of the IPO’s cash proceeds. Therefore, post-IPO accruals are a contaminated measure of strategic earnings management exercised by insiders prior to the IPO.

Ball and Shivakumar (2008) modified the Jones (1991) model to account for conservatism in accruals. In the IPO context, measuring abnormal accruals from such a model is motivated by the view that IPOs report more conservatively than mature firms. Moreover, Ball and Shivakumar (2008) argued against the use of the original Jones (1991) model in IPOs, because it results in an unusually high measure of abnormal accruals. The modification adopted by Ball and Shivakumar

\footnotetext{
${ }^{9}$ We provide evidence on the threat of litigation and enforcement in Table 4.

10 Although the SEC vets IPO documents prior to listing, the SEC audits financial statements only periodically following an IPO.
} 
(2008) allows negative cash flows to be incorporated into accruals at a different speed than positive cash flows. This approach measures normal accruals as the predicted value of regression line (omitting the time index $t$ and individual IPO index $i$ in all equations):

$$
A C C=\beta_{1}+\beta_{2} \Delta \operatorname{Rev}+\beta_{3} F A S S E T+\beta_{4} C F O+\beta_{5} D C F O+\beta_{6} D C F O * C F O+\varepsilon,
$$

where accruals (ACC) is net income before extraordinary items, plus depreciation and amortization minus operating cash flows. $\Delta R e v$ is the change between year $t$ and year $t-1$ in net sales. This model employs the net book value of property, plants, and equipment, FASSET, and operating cash flow, CFO. All aforementioned variables are scaled by total assets at the beginning of the year. $D C F O$ takes the value 1 if $C F O<0$ and 0 otherwise. We winsorize the top and bottom $1 \%$ of each continuous explanatory variable. ${ }^{11}$

We estimate Model 1 in two ways. First, to provide descriptive statistics regarding greater reporting conservatism in IPOs, comparable to Ball and Shivakumar (2008), we measure abnormal accruals in the IPO sample relative to mature US-listed firms. Specifically, based on the entire COMPUSTAT population, but excluding IPOs, we run Model 1 on an industry-year basis and use the regression coefficients to calculate the abnormal accrual variable (ABNACC) for all sample IPOs as follows:

$$
A B N A C C=A C C-\left[\hat{\beta}_{1}+\hat{\beta}_{2} \Delta R e v+\hat{\beta}_{3} F A S S E T+\hat{\beta}_{4} C F O+\hat{\beta}_{5} D C F O+\hat{\beta}_{6} D C F O * C F O\right] .
$$

Second, because our main focus is on the IPO market, we run Model 1 in the main analyses for only the IPO sample and use the resultant coefficients in Model 2. ${ }^{12}$

\footnotetext{
${ }^{11}$ We apply a similar procedure throughout the paper.

12 Due to the limited sample size, and in line with Peek, Meuwissen, Moers, \& Vanstraelen (2013), we combine several years for each industry. Specifically, we use three consecutive years as a single period, as follows: 1990-1994, 1995-1998, 1999-2001, 2002-2005, and 2006-2009. Model 1 is estimated to require at least ten observations.
} 


\subsection{Measuring the Strength of Home Institutions}

The strength of an IPO's home institutions is captured by the variable INST. This variable is based on the classification of legal institutions provided by Leuz (2010). Specifically, in Panel C of Table 3, Leuz (2010) assigns national legal institutions into three clusters based on their variables of regulatory and reporting practices. Countries in the first cluster are regarded as having the strongest institutions. We therefore set INST $=1$ if an IPO comes from this cluster and zero otherwise.

\subsection{Regression Models and Variables}

Our first objective is to examine how the threats of SEC enforcement and private litigation vary between foreign and domestic US IPOs. We also want to examine, within the foreign IPOs subsample, the link between the threats of SEC enforcement, private litigation, and INST, controlling for some other country-specific variables. However, as we subsequently explain, while we have data on private litigation for both US and foreign firms, we do not have data on SEC enforcement for the US. We use a parsimonious model for each threat, as follows:

$$
\begin{aligned}
& S E C_{-} E N F=\alpha+\beta_{1} I N S T+\beta_{2} A G G_{-} E M+\beta_{3} G D P+\varepsilon \\
& P L I T=\alpha+\beta_{1} F O R E I G N / I N S T+\beta_{2} A G G_{-} E M+\beta_{3} G D P+\varepsilon .
\end{aligned}
$$

We run Model 3a using the foreign sample only. The dependent variable-our proxy for the threat of SEC enforcement of foreign firms (SEC_ENF)—is the percentage of firm-year observations with SEC enforcement reported in Table 2 in Silvers (2016) per-foreign country 
sample. ${ }^{13}$ In Model 3b the dependent variable—our proxy for private litigation (PLIT) —is the percentage of firm-years with securities class actions reported in Table 3 in Cheng et al. (2014). ${ }^{14}$ INST features in both models when we use the foreign IPOs subsample. In addition, we run Model 3b on the entire sample while replacing INST with FOREIGN. When using the foreign IPOs sample, finding that $\beta_{1}$ is negative is consistent with the view that perceptions of stronger home institutions are associated with fewer enforcement actions and reduced private litigation. When we run Model $3 \mathrm{~b}$ on the entire sample, finding that $\beta_{1}$ is negative implies that the threat of private litigation is lower for foreign IPOs than domestic US IPOs. Both models feature the same control variables, which may shape the enforcement and private litigation threats. The first variable is the country-level aggregated earnings management measure (AGG_EM), as calculated by Boulton, Smart, \& Zutter (2011). The second variable is the IPO's home country's GDP in the year the IPO takes place.

In analyzing the association between abnormal accruals, $A B N A C C$, and an IPO’s foreign status and home institutions in the IPO sample, we employ the following model:

$$
\begin{aligned}
A B N A C C= & \alpha+\beta_{1} \text { THREAT }+\beta_{2} L I T I G+\beta_{3} A U D+\beta_{4} S O X+\beta_{5} L T A+\beta_{6} L P R O C \\
& +\beta_{7} \text { HiTECH }+\beta_{8} L E V+\beta_{9} L S A L E S+\beta_{10} C F O+\beta_{11} L R O A \\
& +\sum \text { Industry }+\sum \text { Year }+\varepsilon,
\end{aligned}
$$

where THREAT is either SEC_ENF or PLIT. We expect a negative relation between ABNACC and THREAT to the extent that a great risk of enforcement and litigation constrains earnings management.

\footnotetext{
${ }^{13}$ Silvers (2016) did not report a measure of enforcement of US firms. Hence, we run Model 3a on the foreign IPOs subsample. In using Silvers' (2016) Table 2, we implicitly assume that SEC enforcement of mature foreign firms is similar to its enforcement of foreign IPOs. If this assumption is violated, then SEC_ENF is measured with noise and we are less likely to establish significant relations.

${ }^{14}$ We also assume that private litigations rates reported in Cheng et al. (2014) of mature firms are similar for IPOs.
} 
To test the direct effect of foreignness, we define an indictor variable, FOREIGN, which is set equal to 1 if the IPO is a foreign IPO, and zero otherwise. We then run the following model in the full sample, which includes both US IPOs and foreign IPOs:

$$
\begin{aligned}
\text { ABNACC } & =\alpha+\beta_{1} \text { FOREIGN } / \text { INST }+\beta_{2} L I T I G+\beta_{3} A U D+\beta_{4} S O X+\beta_{5} L T A+\beta_{6} L P R O C \\
& +\beta_{7} \text { HiTECH }+\beta_{8} L E V+\beta_{9} L S A L E S+\beta_{10} C F O+\beta_{11} L R O A \\
& +\sum \text { Industry }+\sum \text { Year }+\varepsilon
\end{aligned}
$$

We also test how earnings management varies with home institutions across foreign IPOs by using Model 5 after replacing FOREIGN with INST. Our main coefficient of interest is $\beta_{1}$, the coefficient on FOREIGN (or, INST). When FOREIGN is used in Model 5, this coefficient captures the incremental level of abnormal accruals in foreign IPOs over that of domestic IPOs. When using INST within the subsample of foreign IPOs, this coefficient captures the incremental level of abnormal accruals in foreign IPOs originating from strong-institution countries over that of foreign IPOs from weak-institution countries.

Models 4 and 5 include several common control variables that are organized in three groups: variables capturing other sources of scrutiny, variables capturing incentives to inflate earnings, and other control variables. The first set of control variables includes LITIG, an industry-based indicator for litigation risk consistent with Frankel, Johnson, \& Nelson (2002) and Ashbaugh, LaFond, \& Mayhew (2003). ${ }^{15}$ We control for auditor size, as monitoring by large auditors is stronger than by small auditors (Ball and Shivakumar, 2008; Fan and Wong, 2005; Venkataraman, et al., 2008). Specifically, $A U D$ is an indicator variable that is set equal to 1 if the auditing firm is a Big-6, Big-5 or Big-4 in 1990-1997, 1998-2001, and 2002 onwards, respectively, and 0 otherwise. SOX is an indicator variable that is set equal 1 if the IPO occurred after enactment of

\footnotetext{
${ }^{15}$ The industries that are more prone to US litigation are identified in Francis, Philbrick, \& Schipper (1994).
} 
the Sarbanes-Oxley Act (SOX) in July 2002, and 0 otherwise. Following Cohen, Dey, \& Lys (2008), SOX controls for the possibility that a stricter regulatory environment following SOX influenced earnings management in IPOs. Because larger IPO firms may be subject to greater public attention, we include $L T A$, the log of total assets. The expected sign of the coefficients included in this group is negative.

The second group of control variables includes proxies for incentives to inflate earnings. First, we control for the possibility of earnings management that aims to influence the IPO proceeds. Specifically, we employ the variable $L P R O C$, which is the log of actual proceeds. ${ }^{16}$ Notably, proceeds also act as a measure of the IPO's importance and size. Many IPOs come from the hightech sector. Since such firms may be harder to understand owing to a high level of intangibles (Barth, Beaver, \& Landsman, 2001), managers may have a greater incentive to inflate earnings, because high R\&D expenses depress reported earnings. We therefore include an indicator variable HiTECH for technology firms, as defined by Security Data Corporation (SDC) Platinum and Thomson Reuters. $L E V$ is the ratio of total debt over total assets at the end of the fiscal year preceding the IPO and controls for the possibility that leverage affects earnings management. The expected sign of the coefficients included in this group is positive.

The third group of control variables includes additional firm fundamentals. Although IPO firms are relatively young, an IPO may occur at different stages of the product life cycle, which may influence reporting choices. Assuming life cycle is reflected in recorded sales, we include LSALES, the log of sales at the end of the fiscal year preceding the IPO, which is also commonly used as a measure of risk (Loughran and Ritter, 2004). Lagged return on assets (ROA) (LROA) and operating cash flow $(C F O)$ are included to control for the effect of performance on earnings management

\footnotetext{
${ }^{16}$ We use the actual proceeds because we do not have a measure for target proceeds. Additionally, the results remain the same if instead of the offer price we use is first-trading-day price.
} 
(Gul, Fung, \& Jaggi, 2009; Kothari, Leone, \& Wasley, 2005). ${ }^{17}$ Finally, we include year- and industry-fixed effects.

\subsection{The Sample}

We identify companies from the SDC New Issues database that were first-time issuers between 1990 and 2009 in the US and not previously listed elsewhere. Foreign firms are incorporated firms whose primary executive offices are located outside of the US (Bruner, Chaplinsky, \& Ramchand, 2006). ${ }^{18}$ We exclude equity listings that originated from spin-offs of publicly listed companies or from mergers and acquisitions. We further eliminate warrants, units and rights offerings, and utility firms and financial service firms based in the Bahamas, Cayman Islands, and Bermuda for tax purposes. We also exclude all firms with insufficient financial data.

Panel A of Table 1 provides information regarding the sample formation analyzed between foreign and domestic IPOs. Panel B presents the sample industry composition according to the Fama-French (FF) 12-industry classification. This panel shows that the largest group of IPOs in the sample is from the Business Equipment industry (FF6), followed by Healthcare, Medical Equipment, and Drugs (FF10). Panel C reports the distributions of IPOs according to the country of origin in five periodic windows from $1990-2009 .{ }^{19}$ Consistent with other studies on foreign issuers in the US, the largest number of IPOs is from Israel (64), followed by China (46), the UK (32), and Canada (29). Most of the IPOs take place before 2001, when the internet and dot.com bubble burst.

\footnotetext{
${ }^{17}$ If Model 1 is correctly specified, $C F O$ is orthogonal to abnormal accruals (the error term in (1)). However, if Model 1 suffers from an omitted variable problem, $A B N A C C$ and $C F O$ may be correlated. It is plausible that without $C F O$, Eq. (3) may suffer from the same problem. Hence, including $C F O$ in (3) helps to mitigate the omitted correlated variable problem.

18 We confirmed that the SEC defines foreign IPOs in our sample as foreign registrants (see https://www.sec.gov/divisions/corpfin/internatl/companies.shtml).

${ }^{19}$ These periods were also used in estimating Model 1.
} 
We manually extract many of the variables needed for the empirical investigation from each foreign firm's prospectus. We complement this by searching the SEC's Edgar database and the Perfect Filing database. Foreign currency figures are translated into US dollar figures based on the exchange rates disclosed in the prospectuses. We obtain financial information of the domestic US IPOs from COMPUSTAT and SDC Platinum. Importantly, financial information in the foreign prospectuses is prepared under US GAAP. Hence, changes in home countries' accounting rules are not expected to influence our findings. ${ }^{20}$ We index monetary variables to the 2005 US dollar value based on the Consumer Price Index (CPI) as reported by the International Monetary Fund. ${ }^{21}$

\section{[Insert Table 1 about here]}

Table 2 reports summary statistics for the variables used in the empirical analysis. Panel A presents a summary for abnormal accruals measured using mature US firms and the IPO sample as the two benchmarks for estimating Model 1. The table also reports descriptive statistics for the full sample, the domestic US IPO subsample, and the foreign IPOs subsample, as well as a univariate analysis of differences between the two subsamples. Using the mature firms' benchmark, the mean of $A B N A C C$ is negative and statistically different from zero, suggesting that IPO firms are more conservative than mature firms. This finding is consistent with heightened scrutiny and monitoring effects that dominate incentives to inflate pre-IPO earnings (Ball and Shivakumar, 2008). While both domestic and foreign IPOs are conservative relative to mature firms, a comparison of the means and medians indicates domestic IPOs are more conservative than

\footnotetext{
${ }^{20}$ In our sample there are only nine IPOs that report under IFRS. Nevertheless, in Section 5.5 we investigate whether IFRS adoption in the IPO's home country affects the results.

${ }^{21}$ Retrieved from http://www.imf.org/external/data.htm\#data on April 2011.
} 
foreign IPOs. This finding is also the case when abnormal accruals are measured within the IPO sample, which provides preliminary evidence with respect to our first research question. ${ }^{22}$

Turning to the IPO sample, it is evident that the domestic IPOs and foreign IPOs subsamples are different, apart from leverage. ${ }^{23}$ The mean of INST is lower in foreign IPOs than in domestic US IPOs, which is consistent with US legal institutions being stronger than foreign institutions, on average. Foreign IPOs attract higher proceeds, as seen from LPROC. Foreign IPOs are larger and report higher sales. Inspecting $C F O$ and $L R O A$ indicates that foreign IPOs perform better than their domestic counterparts, as per prospectus financials.

Panel B further analyzes the foreign IPOs subsample, distinguishing between home countries with strong (INST=1) and weak (INST=0) institutions, based on whether the IPO country of origin is from the first cluster in Leuz (2010) or otherwise, (i.e., strong and weak respectively). This results in classifying $56 \%$ of the observations as strong home institutions. A comparison of abnormal accruals (ABNACC) indicates that foreign IPOs with weak home institutions are more conservative than foreign IPOs with strong home institutions, on average. Note that IPOs with weak home institutions employ relatively larger auditors, generate more sales and CFO, and raise more money from the IPO.

In an untabulated analysis we compare the statistics for each variable used for the estimation of abnormal accrual levels in the pooled IPO sample. We find mean accruals (ACC) is significantly more negative in domestic IPOs, indicating greater conservatism in domestic IPOs. The mean indicator for negative CFO (DCFO) is significantly higher in the domestic subsample, consistent with Panel A.

\footnotetext{
${ }^{22}$ In the remainder of the paper, $A B N A C C$ is measured with respect to the IPO sample.

${ }^{23}$ To address the differences between the samples, we run robustness tests (unreported) that restrict the domestic USfirm sample to observations with LTA and LPROC of at least the minimum values of these variables in the foreign sample. These did not yield any material differences in our findings.
} 
[Insert Table 2 about here]

Table 3 reports the correlation coefficients for the various variables. The correlation between ABNACC and FOREIGN is small, suggesting little effect of foreignness on signed abnormal accruals in a single factor analysis. The correlation between the abnormal accruals measure and INST is insignificant. INST and FOREIGN are highly and negatively correlated, since INST assumes highest values for US IPOs that are $75 \%$ of the entire sample. Therefore, we do not use both variables in the same regression model. No correlation value is reported for FOREIGN with SEC_ENF, since we do not have a measure of SEC enforcement for domestic US firms. The correlation between FOREIGN and PLIT is -0.70, consistent with lower private litigation in foreign firms. Relatively high and negative correlations are shared between HOME_ENF, SEC_ENF, PLIT on one hand and INST on the other hand. However, INST is not used together with these three variables in any of the tests. All other correlations are quite small with the exception of the correlation between $L R O A$ and $C F O$. We nevertheless verify that multicollinearity does not affect our inferences in subsequent analyses.

[Insert Table 3 about here]

\section{Main Findings}

\subsection{Threats of Enforcement and Private Litigation}

As explained in Section 3.3, we first aim to establish if the threat of private litigation is lower for foreign firms using Model 3b. ${ }^{24}$ We run it with two specifications. The first includes all individual IPOs and the second is run at the country level. Accordingly, in the second specification, $G D P$ is replaced with GDP_Av, which is a country-level average based on the years in which IPOs

\footnotetext{
${ }^{24}$ We do not have a measure of SEC enforcement for domestic IPOs that are comparable to the measures we use for foreign IPOs.
} 
from that country took place. The advantage of the first approach is that the sample reflects IPO frequency for each country. Such frequency may also influence the frequency of enforcement and litigation. In the second specification, this frequency does not play a role, as each country appears only once. The main variable of interest in these specifications is FOREIGN. We find that the coefficient on FOREIGN is negative and highly significant in both specifications ( $p$-value $<0.01$ ) (results are untabulated). This is consistent with a lower threat of private litigation for foreign IPOs than domestic US IPOs.

Next, we run Models 3a (for SEC_ENF) and 3b (for PLIT) using the foreign IPOs subsample, in which INST is the main variable of interest. Here, too, we use the abovementioned two specifications (firm level and country level). Panel A of Table 4 presents the estimation results. Starting with SEC enforcement, the coefficient on INST is negative and highly significant in both specifications. This is consistent with the SEC directing more enforcement resources to IPOs originating from countries with weak institutions. With private litigation, we find a similar result in the first specification, but not in the country-level specification. ${ }^{25}$ We note, however, that for this specification we have the smallest number of observations. Overall, we infer from these findings IPOs from foreign countries are sued less than domestic US IPOs, and IPOs originating from countries with weak institutions are exposed to greater enforcement and litigation threats than IPOs originating from countries with strong institutions.

Panel B reports the results for Model 4, which examines the relation between signed abnormal accruals and SEC enforcement threat (Columns 1-3), or private litigation threat (Columns 4-6). Starting with SEC enforcement, in Column 1 we use the entire foreign IPO sample. Here the coefficient on SEC_ENF is negative and significant at 1\%, suggesting that a stronger enforcement

\footnotetext{
${ }^{25}$ For PLIT we have fewer observations as we do not have data for all countries (mainly Canada).
} 
threat reduces abnormal accruals. In Column 2 we repeat this analysis while restricting the sample to foreign IPOs from strong institutions countries. Consistent with lower enforcement threat for these IPOs, we find no constraining effect for SEC_ENF on abnormal accruals. In contrast, in Column 3, in which we focus on IPOs from countries with weak institutions, the coefficient on SEC_ENF is negative and significant at less than $6 \%$. This is consistent with a stronger enforcement threat for IPOs originating from countries with weak legal institutions. The difference in the coefficient on SEC_ENF between the two subsamples is 15.957 and it is highly significant $(p$-value $=0.002)$. When we repeat the analysis using the threat of private litigation (Columns $4-$ 6), the results are similar in nature. That is, a greater threat of private litigation is associated with less earnings management for IPOs originating from countries with weak home institutions. ${ }^{26}$ However, the difference in the coefficient on PLIT between the two subsamples is 0.078 , and it is statistically insignificant. In untabulated analysis we also run Model 4 on the entire IPO sample using PLIT as the main variable of interest. We find the coefficient on PLIT is negative and significant $(p$-value $=0.045)$. This is consistent with domestic US IPOs that face a greater threat of private litigation and hence manage earnings less aggressively than foreign IPOs.

Inspecting controls that are statistically significant, we offer two noteworthy observations. First, there seems to be a constraining effect for large auditors. Second, foreign high-tech firms report more conservatively. However, both results are confined to IPOs from weak home institutions.

Taken together, the results reported in Table 4 suggest enforcement and private litigations threats are stronger for foreign IPOs originating from countries characterized by weaker legal institutions. Consequently, these IPOs manage earnings less than IPOs from countries characterized by strong institutions, consistent with $\mathrm{H} 2$.

\footnotetext{
${ }^{26}$ We also verified that these results are robust to self-selection. We discuss self-selection in Section 5.1.
} 
[Insert Table 4 here]

\subsection{Abnormal Accruals, IPO Foreignness, and Home Institutions}

In Table 4 we examine the relation between the threats of enforcement and litigation and earnings management in foreign IPOs. Our next analysis, reported in Table 5, concerns the direct link between home institutions and foreignness on one hand, and earnings management on the other hand. Starting with the foreign IPOs subsample (Column 1), the coefficient on INST is positive $(p$-value $=0.039)$. This finding implies abnormal accruals are larger in foreign IPOs from strong institutions countries and is consistent with lower litigation and enforcement threats for these IPOs. Column 2 reports the results for the full sample where FOREIGN replaces INST; this allows us to compare earnings management in foreign IPOs relative to domestic US IPOs (our H1). Here the coefficient on FOREIGN is positive and significant at 3.5\%, indicating earnings inflation is higher at foreign IPOs, which is consistent with H1. In Column 3 we repeat this analysis by adding an indicator variable for foreign IPOs that originate from strong home institutions (FOREIGN_STRONG_INST). Under this specification, FOREIGN captures the average degree by which abnormal accruals in foreign IPOs from weak home institutions exceed abnormal accruals in domestic US IPOs; FOREIGN_STRONG_INST then captures the incremental effect on abnormal accruals for foreign IPOs from strong institutions over foreign IPOs from weak institutions. The finding that the coefficient on FOREIGN is insignificant indicates earnings management in domestic IPOs and foreign IPOs from weak institutions is similar in magnitude, on average. The positive and highly significant coefficient for FOREIGN_STRONG_INST indicates that abnormal accruals are higher, on average, in IPOs from strong institutions than both US firms and other foreign firms. In Column 4 we use the subsample of foreign IPOs from strong institutions countries. Here the coefficient on FOREIGN is positive and significant ( $p$-value = 
0.01), consistent with higher earnings management in foreign IPOs from strong institutions countries than domestic US IPOs. In Column 5 we compare IPOs from weak home institutions to domestic US IPOs and find that the coefficient on FOREIGN is insignificant.

[Insert Table 5 here]

On the whole, we conclude from Table 5 that foreign IPOs inflate earnings more than domestic US IPOs, consistent with H1. In addition, supporting H2, the evidence indicates that within foreign IPOs, earnings inflation increases with the IPO’s strength of home country institutions, as implied by the threats of lower enforcement and private litigation.

\section{Additional Analyses}

\subsection{Self-selection}

One concern with the abovementioned findings is that the coefficients are inconsistent owing to a selection bias. Specifically, we know from Panel B of Table 2 that IPOs from countries with strong institutions tend to come from the high-tech sector, are smaller, less profitable, and raise smaller proceeds. The pressure to raise funds may favor listing in the richer US market, especially for loss-making firms. Once deciding to list in the US, such fledgling firms also face stronger incentives to inflate earnings. To address the selection bias, we run a two-step procedure following Heckman (1979). ${ }^{27}$ In the first step we estimate the probability of listing in the US (US_Listing). Here US_Listing = 1 for foreign IPOs conducted in the US, or both in the US and home country $(N=300)$, while $U S \_L i s t i n g=0$ for IPOs conducted exclusively outside the US $(N=1,396)$. Specifically, we identify and select from SDC Platinum all IPOs conducted only in the home country of the foreign IPOs in our sample in the same year and industry (using an FF12

\footnotetext{
${ }^{27}$ A similar approach has been used in the cross-listing literature (e.g., Doidge, Karolyi, \& Stulz, 2004, 2010; Loureiro, 2010).
} 
classification). In the second step we re-run Table 5 after including the inverse Mills ratios (IMR) computed from the first step. Following guidance in Lennox, Francis, \& Wang (2011), the model in the first step uses a number of determinants of the decision to list in the US, several of which are excluded from the second step. Doidge et al. (2004, 2010) advocated the use of country-level instruments in the first stage (the selection stage). Several home country-level variables (other than INST) likely affect the listing decision, but are less likely to influence earnings management in the US. In accordance with this guidance, we include the home country's GDP (GDP) to proxy for the size of the home country's capital market and a measure of a country's aggregate earnings management (AGG_EM, taken from Table 2 in Boulton et al., 2011). We add a measure of home enforcement, $\left(H O M E \_E N F\right)^{28}$ to control for Licht's (2003) suggestion that strict home regulation can cause local firms to conduct an IPO in the US. ${ }^{29}$ We also add our measures of SEC enforcement and private litigation threats, as these may deter a US listing, in which case we expect to find a negative coefficient. At the same time, these threats may attract a US listing by companies that want to signal their commitment to good governance. The selection of first-step regressors also includes several variables used in the second step, since they are likely related to both the listing decision and earnings management. LTA is included for firm size, LPROC proxies the intended size of the IPO, and HiTECH is included because high-technology firms likely find a US exchange more attractive (Caglio, Hanley, \& Marietta-Westberg, 2016). The selection model (first step) is:

\footnotetext{
${ }^{28}$ We use the country enforcement index as measured and presented in Brown, Preiato, \& Tarca (2014) by the country of origin of the foreign IPO and the IPO year. This index includes the US as well as our IPO foreign countries. This measure is excluded from the other models, as we do not expect enforcement in the country of origin to affect earnings management in US filings.

${ }^{29}$ We report pairwise correlations of HOME_ENF with other variables used in this study in Table 3. Notably, the correlation of HOME_ENF with FOREIGN is highly negative (at 0.60 ), since enforcement is strongest in the US. The correlation with INST is 0.40 , as would be expected. In addition, the correlation with SOX is 0.60 reflecting increasing enforcement scores over time as documented in Brown et al. (2014).
} 


$$
\begin{aligned}
\operatorname{Pr}\left(U S_{-} \text {Listing }\right) & =\alpha+\beta_{1} L T A+\beta_{2} L P R O C+\beta_{3} A G G_{-} E M+\beta_{4} H O M E \_E N F \\
& +\beta_{5} S E C_{-} E N F+\beta_{6} P L I T+\beta_{7} H i T E C H+\beta_{8} G D P+\varepsilon .
\end{aligned}
$$

Table 6 reports the results of this two-step procedure, with Panel A providing the results of the first step (the selection Model 6). Across the five columns of this panel, we present results for different combinations of HOME_ENF, SEC_ENF, and PLIT. When an IPO's home enforcement is included on its own (Column 1), we find that it is positively related to the probability of US listing. However, when all three threat variables are included (Column 5), home enforcement turns insignificant. SEC_ENF is positively related to the probability of US listing regardless of whether it appears as the only threat variable or in a combination with any of the other two. We find no evidence the threat of private litigation in the US deters, or attracts, a US listing. Examining the other variables, we find that the likelihood of a US listing for a foreign firm increases in firm size and expected proceeds. High-tech firms are also more likely to conduct their IPOs in the US (Caglio et al., 2016). Size of the home country's economy is negatively related to the listing probability. We also find evidence that the country level of earnings management explains the US listing decision (Column 2, 4-5).

In Panel B of Table 6, we report the results of estimating Model 5 after the inclusion of the inverse Mills ratios obtained from each one of the five columns of Panel A. For brevity, we only report the coefficient on INST and on the inverse Mills ratios (IMR) obtained from the selection model. Across the five versions of the Mills ratios, the results are qualitatively similar to Column 1 in Table 5. Specifically, the coefficient on INST is positive and statistically significant at the 5\% level in the two rightmost models. The coefficients on IMR are statistically insignificant, suggesting that the selection bias, if any, is not directly related to earnings management by the foreign IPO.

[Insert Table 6 here] 


\subsection{Insider Ownership, VC Backing, and Underwriter's Rank}

Leuz (2006) argued that it is important to control for insider ownership in international studies of earnings management. Because ownership structures may be strongly influenced by home institutions, it is unclear if FOREIGN or INST capture differences in ownership structures rather than in underlying institutions. Therefore, we augment our main regression specifications (Tables 4 and 5) by adding a control variable, INSIDER, which measures the percentage of stocks retained by original IPO owners following the IPO. The average value for INSIDER is high (0.728), and it is virtually identical across domestic US IPOs and foreign IPOs. ${ }^{30}$ In multivariate analyses we do not find that insider ownership is associated with signed abnormal accruals (not tabulated). This stands in contrast to Leuz (2006)'s finding of a positive relation between earnings management and insider ownership in cross-listed firms. With regard to our main findings (Tables 4 and 5), the signs and significance levels of the coefficients on SEC_ENF, PLIT, FOREIGN, and INST remain similar to those reported previously. We therefore conclude that our results do not reflect ownership-driven incentives to engage in earnings management.

In the main specification we use auditor size to capture monitoring mechanisms that likely constrain earnings management. Clearly, auditors are not the only agents that play such a role. The IPO literature has identified a similar role with venture capitalists (VC) (Chahine, Arthurs, Filatotchev, \& Hoskisson, 2012; Nam, Park, \& Arthurs, 2014) and reputable underwriters (Carter and Manaster, 1990). We therefore further control for VC backing and underwriters' ranking by adding an indicator variable $V C$ and a control variable $U W \_R a n k$ to the main regression specifications (Tables 4 and 5). VC is an indicator variable that is set equal to 1 when the IPO is backed by a VC, as identified in SDC Platinum and 0 otherwise. UW_Rank is the rank of the

\footnotetext{
${ }^{30}$ Insider ownership is similar in foreign IPOs from countries with strong home institutions and in foreign IPOs from countries with weak home institutions.
} 
leading underwriter, as identified in SDC Platinum and reported on Jay Ritter's website. ${ }^{31}$ The average value for $U W \_R a n k$ is 7.85 , and it is virtually identical across domestic US IPOs and foreign IPOs. A t-test on VC reveals that the number of VC-backed US IPOs is larger than foreign IPOs. Adding these variables largely does not alter our main inferences from Tables 4 and $5^{32}$ (not tabulated).

\subsection{IPO Multi-listings}

While most of our foreign IPOs list their stock exclusively in the US, in our sample 65 foreign firms simultaneously conduct an IPO in the US and in their home countries. ${ }^{33}$ Our results may be therefore attributed to the fact that such firms cannot exclusively bond to US regulations. We thus add to Models 4 and 5 an indicator variable (MULTI) if an observation belongs to a simultaneous foreign IPO. If incentives to report conservatively in pre-IPO earnings were stronger (weaker) for multi-country IPOs (owing to an additional and dilutive monitoring effect), we would expect to find that the coefficient on MULTI is negative (positive). In an untabulated analysis we find that Panel B of Table 4 and Table 5 remain intact after adding MULTI to the regression specification.

\subsection{Choice of US Exchange}

Foreign IPOs can choose on which US exchange to list their stock. Frost, Gordon, \& Hayes (2006) argued that disclosure rules, monitoring, and enforcement may vary across exchanges and that exchange membership can thus add an extra layer of monitoring and enforcement over and above that set by the SEC and other regulators. It is possible that exchange membership is correlated with FOREIGN and INST because IPOs from the same country may flock to the same

\footnotetext{
${ }^{31} \mathrm{http}: / /$ bear.warrington.ufl.edu/ritter/ipodata.htm

32 In Column 6 of Panel B of Table 4 (the subsample of foreign IPOs from weak institutions countries) PLIT turns insignificant once we control for VC backing. However, PLIT remains negative in the entire foreign sample.

${ }^{33}$ This multi-listing involves 19 foreign countries, with the UK leading the other markets (15 observations).
} 
exchange and benefit from sharing listing experience. If the exchange-listing decision is driven by factors that are correlated with home institutions, we may be incorrectly attributing our results to the IPO's home country's security laws. To test this idea, we add indicators for NYSE and AMSE in Models 4 and 5. Our main findings are robust to this modification.

\subsection{Changes in Reporting Standards in Home Countries}

As our sample period is quite long, possible changes in home institutions over time may influence our findings. In particular, the adoption of International Financial Reporting Standards (IFRS) and a greater enforcement threat in home countries may have affected incentives to inflate earnings in the prospectus of an IPO. However, we have only nine observations where IFRS is used; hence we do not have enough variation in the data to explore an IFRS effect. Nonetheless, in 68 observations, foreign IPOs use home GAAP and reconcile to US GAAP. We examine whether this group drives our results by adding an indicator for reconciliations in Models 4 and 5 . In both Tables 4 and 5 controlling for reconciliations does not alter our inferences, after adding this indicator.

\subsection{Pricing of Abnormal Accruals}

While earnings management may be associated with several incentives, one possible explanation debated in the literature is attempts by managers to influence stock prices. It has been proposed an equilibrium exists whereby investors expect managers to inflate earnings and given this belief, managers’ best reaction is to meet these expectations (Shivakumar, 2000; Stein, 1989). However, in this equilibrium, investors do not price abnormal accruals, on average. To investigate the pricing implications of abnormal accruals in our setting, we regress the following model: 


$$
\begin{aligned}
M T A & =\alpha+\beta_{1} \text { ABNACC }+\beta_{2} \text { FOREIGN or INST }+\beta_{3} L I T I G+\beta_{4} A U D+\beta_{5} S O X+\beta_{6} L T A \\
& +\beta_{7} L P R O C+\beta_{7} H i T E C H+\beta_{8} L E V+\beta_{9} L S A L E S+\beta_{10} C F O+\beta_{11} L R O A \\
& +\sum \text { Industry }+\sum \text { Year }+\varepsilon .
\end{aligned}
$$

The dependent variable in Model 7 is the market value of the IPO at the beginning of the first trading day, scaled by pre-IPO total assets. The main variable of interest is ANBACC. We report the results in Table 7, which is structured similarly to Table 5. Across all four columns of this table, the coefficient on $A B N A C C$ is insignificant, indicating that abnormal accruals are not priced regardless of IPOs' country of origin. ${ }^{34}$ Additionally, in Column 1 the coefficient on INST is negative, while in Column 3 the coefficient on FOREIGN is lower than the same coefficient in Column 4 (0.128 vs. 0.318). Taken together, these results suggest IPOs originating from stronginstitution countries attract lower valuations, on average, than IPOs from weak-institution countries and their pricing is closer to the pricing of US IPOs. When all foreign IPOs are pooled together with domestic US IPOs (Column 2), the coefficient on FOREIGN is positive and highly significant. This suggests that investors in the primary market assign a price premium to foreign IPOs relative to domestic IPOs, although the price premium is lower for IPOs originating from strong-institution countries. ${ }^{35}$

\section{Summary and Conclusions}

We provide evidence pertaining to the bonding hypothesis in the context of the US IPO market. Our results suggest higher SEC enforcement and private litigation threats for IPOs originating from countries with weak institutions than IPOs from countries with strong institutions. Greater enforcement and litigations threats, in turn, are associated with reduced earnings management.

\footnotetext{
${ }^{34}$ These findings hold also when we drop FOREIGN and INST from the model specification and when we control for self-selection in Column 1.

${ }^{35} \mathrm{~A}$ further analysis of the pricing implications of FOREIGN is beyond the scope of this paper.
} 
This is particularly pronounced for IPOs originating from countries with weak institutions (that manage earnings at levels similar to domestic US IPOs). However, we do not find that earnings management is priced.

As our results suggest that enforcement and litigation are not applied with a similar force to domestic and foreign IPOs, we conclude the bonding hypothesis does not seem to hold in this market. The reasons we provide for this finding relate to how the liability of foreignness in the US IPO market is likely associated with perceptions of (or trust in) foreign institutions. In particular, we conclude the degree of bonding is inversely related to the strength of foreign institutions. We rule out several alternative explanations that may be behind this relation, including selection bias, insider ownership, and choice of US exchange.

The result that bonding is inversely related to institutions is surprising in light of prior research that has found mature cross-listed firms from countries with weak legal institutions inflate earnings to a greater extent than similar firms from strong home institutions. Future research can further explore the reasons for such differences between the main and secondary markets. 


\section{References}

Aharony, J., Lin, C. J., \& Loeb, M. P. (1993). Initial Public Offerings, accounting choices, and earnings management. Contemporary Accounting Research, 10(1), pp. 61-81.

Amir, E., Harris, T. S., \& Venuti, E. K. (1993). A comparison of the value-relevance of US versus nonUS GAAP accounting measures using form 20-F reconciliations. Journal of Accounting Research, 31(Supplement), pp. 230-264.

Anderson, C. W., Fedenia, M., Hirschey, M., \& Skiba, H. (2011). Cultural influences on home bias and international diversification by institutional investors. Journal of Banking \& Finance, 35(4), pp. 916-934.

Ashbaugh, H., LaFond, R., \& Mayhew, B. W. (2003). Do nonaudit services compromise auditor independence? Further evidence. The Accounting Review, 78(3), pp. 611-639.

Ball, R., Robin, A., \& Sadka, G. (2008). Is financial reporting shaped by equity markets or by debt markets? An international study of timeliness and conservatism. Review of Accounting Studies, 13(2), pp. 168-205.

Ball, R., \& Shivakumar, L. (2008). Earnings quality at initial public offerings. Journal of Accounting and Economics, 45(2-3), pp. 324-349.

Barth, M., Beaver, W., \& Landsman. (2001). The relevance of the value relevance literature for financial accounting standard setting: another view. Journal of Accounting and Economics, 31(1), pp. 77104.

Bell, G., Filatotchev, I., \& Aguilera, R. (2014). Corporate governance and investors' perceptions of foreign IPO value: An institutional perspective. Academy of Management Journal, 57(1), pp. 301320.

Blankespoor, E., Hendricks, B. E., \& Miller, G. S. (2017). Perceptions and price: Evidence from CEO presentations at IPO roadshows. Journal of Accounting Research, 55(2), pp. 275-327.

Boulton, T. J., Smart, S. B., \& Zutter, C. J. (2011). Earnings quality and international IPO underpricing. The Accounting Review, 86(2), pp. 483-505.

Brown, P., Preiato, J., \& Tarca, A. (2014). Measuring country differences in enforcement of accounting standards: An audit and enforcement proxy. Journal of Business Finance \& Accounting, 41(1-2), pp. 1-52.

Bruner, R., Chaplinsky, S., \& Ramchand, L. (2006). Coming to America: IPOs from emerging market issuers. Emerging Markets Review, 7(3), pp. 191-212.

Bushman, R. M., \& Piotroski, J. D. (2006). Financial reporting incentives for conservative accounting: The influence of legal and political institutions. Journal of Accounting and Economics, 42(1), pp. 107-148. 
Bushman, R. M., Piotroski, J. D., \& Smith, A. J. (2004). What determines corporate transparency? Journal of Accounting Research, 42(2), pp. 207-252.

Caglio, C., Hanley, K. W., \& Marietta-Westberg, J. (2016). Going public abroad. Journal of Corporate Finance, 41, pp. 103-122.

Carter, R., \& Manaster, S. (1990). Initial public offerings and underwriter reputation. The Journal of Finance, 45(4), pp. 1045-1067.

Chahine, S., Arthurs, J. D., Filatotchev, I., \& Hoskisson, R. E. (2012). The effects of venture capital syndicate diversity on earnings management and performance of IPOs in the US and UK: An institutional perspective. Journal of Corporate Finance, 18(1), pp. 179-192.

Cheng, B., Srinivasan, S., \& Yu, G. (2014). Securities litigation risk for foreign companies listed in the US. Working paper, Harvard Business School. Available on http://papers.ssrn.com/sol3/papers.cfm?abstract_id=2163864

Coffee, J. C. (1999). Privatization and corporate governance: The lessons from securities market failure. Journal of Corporation Law, 25, pp. 1-39.

Coffee, J. C. (2002). Racing towards the top?: The impact of cross-listings and stock market competition on international corporate governance. Colum.Bus.L.Rev., 102(7), pp. 1757-1831.

Cohen, D. A., Dey, A., \& Lys, T. Z. (2008). Real and accrual-based earnings management in the pre-and post-Sarbanes-Oxley periods. The Accounting Review, 83(3), pp. 757-787.

Correia, M. M. (2014). Political connections and SEC enforcement. Journal of Accounting and Economics, 57(2), pp. 241-262.

Coval, J. D., \& Moskowitz, T. J. (1999). Home bias at home: Local equity preference in domestic portfolios. The Journal of Finance, 54(6), pp. 2045-2073.

Cox, J. D., Thomas, R. S., \& Kiku, D. (2003). SEC enforcement heuristics: An empirical inquiry. Duke Law Journal, 53(2), pp. 737-779.

Doidge, C., Karolyi, G. A., \& Stulz, R. M. (2004). Why are foreign firms listed in the US worth more? Journal of Financial Economics, 71(2), pp. 205-238.

Doidge, C., Karolyi, G. A., \& Stulz, R. M. (2010). Why do foreign firms leave US equity markets? The Journal of Finance, 65(4), pp. 1507-1553.

Fan, J. P. H., \& Wong, T. J. (2005). Do external auditors perform a corporate governance role in emerging markets? Evidence from East Asia. Journal of Accounting Research, 43(1), pp. 35-72.

Fanto, J. A. (1996). The absence of cross-cultural communication: SEC mandatory disclosure and foreign corporate governance. Journal of International Law and Business, 17, pp. 119-207.

Francis, J., Philbrick, D., \& Schipper, K. (1994). Shareholder litigation and corporate disclosures. Journal of Accounting Research, 32(2), pp. 137-164. 
Frankel, R. M., Johnson, M. F., \& Nelson, K. K. (2002). The relation between auditors' fees for nonaudit services and earnings management. The Accounting Review, 77(Supplement), pp. 71-105.

Frost, C. A., Gordon, E. A., \& Hayes, A. F. (2006). Stock exchange disclosure and market development: an analysis of 50 international exchanges. Journal of Accounting Research, 44(3), pp. 437-483.

Gomes, A. (2000). Going public without governance: managerial reputation effects. The Journal of Finance, 55(2), pp. 615-646.

Greif, A. (1994). Cultural beliefs and the organization of society: A historical and theoretical reflection on collectivist and individualist societies. Journal of Political Economy, 102(5), pp. 912-950.

Grinblatt, M., \& Keloharju, M. (2001). How distance, language, and culture influence stockholdings and trades. The Journal of Finance, 56(3), pp. 1053-1073.

Gu, Y. J., Filatotchev, I., Bell, R. G., \& Rasheed, A. A. (2018). Liability of foreignness in capital markets: Institutional distance and the cost of debt. Journal of Corporate Finance, Forthcoming

Guiso, L., Sapienza, P., \& Zingales, L. (2008). Trusting the stock market. The Journal of Finance, 63(6), pp. 2557-2600.

Guiso, L., Sapienza, P., \& Zingales, L. (2009). Cultural biases in economic exchange? The Quarterly Journal of Economics, 124(3), pp. 1095-1131.

Gul, F. A., Fung, S. Y. K., \& Jaggi, B. (2009). Earnings quality: Some evidence on the role of auditor tenure and auditors' industry expertise. Journal of Accounting and Economics, 47(3), pp. 265287.

Heckman, J. J. (1979). Sample Selection Bias as a Specification Error. Econometrica, 47(1), pp. 153161.

Jones, J. J. (1991). Earnings management during import relief investigations. Journal of Accounting Research, 29(2), pp. 193-228.

Karolyi, G. A. (2012). Corporate governance, agency problems and international cross-listings: A defense of the bonding hypothesis. Emerging Markets Review, 13(4), pp. 516-547.

Kedia, S., \& Rajgopal, S. (2011). Do the SEC's enforcement preferences affect corporate misconduct? Journal of Accounting and Economics, 51(3), pp. 259-278.

Kothari, S. P., Leone, A. J., \& Wasley, C. E. (2005). Performance matched discretionary accrual measures. Journal of Accounting and Economics, 39(1), pp. 163-197.

La Porta, R., Lopez-de-Silanes, F., Shleifer, A., \& Vishny, R. (2002). Investor protection and corporate valuation. The Journal of Finance, 57(3), pp. 1147-1170.

Lang, M., Raedy, J., \& Wilson, W. (2006). Earnings management and cross listing: Are reconciled earnings comparable to US earnings? Journal of Accounting and Economics, 42(1-2), pp. 255283. 
Larcker, D. F., Richardson, S. A., \& Tuna, I. (2007). Corporate governance, accounting outcomes, and organizational performance. The Accounting Review, 82(4), pp. 963-1008.

Lee, G., \& Masulis, R. W. (2011). Do more reputable financial institutions reduce earnings management by IPO issuers? Journal of Corporate Finance, 17(4), pp. 982-1000.

Lennox, C. S., Francis, J. R., \& Wang, Z. (2011). Selection models in accounting research. The Accounting Review, 87(2), pp. 589-616.

Leuz, C. (2006). Cross listing, bonding and firms' reporting incentives: A discussion of Lang, Raedy and Wilson (2006). Journal of Accounting and Economics, 42(1-2), pp. 285-299.

Leuz, C. (2010). Different approaches to corporate reporting regulation: How jurisdictions differ and why. Accounting and Business Research, 40(3), pp. 229-256.

Leuz, C., Nanda, D., \& Wysocki, P. D. (2003). Earnings management and investor protection: an international comparison. Journal of Financial Economics, 69(3), pp. 505-527.

Licht, A. N. (2000). Genie in a bottle? Assessing managerial opportunism in international securities transactions. Colum.Bus.L.Rev., 2000, pp. 51-120.

Licht, A. N. (2003). Cross-listing and corporate governance: bonding or avoiding. Chicago Journal of International Law, 4, pp. 141-163.

Loughran, T., \& Ritter, J. (2004). Why has IPO underpricing changed over time? Financial Management, 33(3), pp. 5-37.

Loureiro, G. (2010). The reputation of underwriters: A test of the bonding hypothesis. Journal of Corporate Finance, 16(4), pp. 516-532.

Lowry, M., \& Shu, S. (2002). Litigation risk and IPO underpricing. Journal of Financial Economics, 65(3), pp. 309-335.

Malloy, C. J. (2005). The geography of equity analysis. The Journal of Finance, 60(2), pp. 719-755.

Merton, R. C. (1987). A simple model of capital market equilibrium with incomplete information. The Journal of Finance, 42(3), pp. 483-510.

Moore, C. B., Bell, R. G., Filatotchev, I., \& Rasheed, A. A. (2012). Foreign IPO capital market choice: Understanding the institutional fit of corporate governance. Strategic Management Journal, 33(8), pp. 914-937.

Nahata, R., Hazarika, S., \& Tandon, K. (2014). Success in global venture capital investing: do institutional and cultural differences matter? Journal of Financial and Quantitative Analysis, 49(4), pp. 1039-1070.

Nam, D. i., Park, H. D., \& Arthurs, J. D. (2014). Looking attractive until you sell: Earnings management, lockup expiration, and venture capitalists. Journal of Management Studies, 51(8), pp. 1286-1310. 
Ndubizu, G. A. (2007). Do cross-border listing firms manage earnings or seize a window of opportunity? The Accounting Review, 82(4), pp. 1009-1030.

$\begin{array}{lllll}\text { NYSE. } & \text { (2013). } & \text { IPO } & \text { Guide. } & \text { Retrieved }\end{array}$ https://www.nyse.com/publicdocs/nyse/listing/nyse_ipo_guide.pdf

Peek, E., Meuwissen, R., Moers, F., \& Vanstraelen, A. (2013). Comparing abnormal accruals estimates across samples: An international test. European Accounting Review, 22(3), pp. 533-572.

Sarkissian, S., \& Schill, M. J. (2003). The overseas listing decision: New evidence of proximity preference. The Review of Financial Studies, 17(3), pp. 769-809.

Scott, W. R. (1995). Institutions and organizations. Foundations for organizational science. London: A Sage Publication Series

Shivakumar, L. (2000). Do firms mislead investors by overstating earnings before seasoned equity offerings? Journal of Accounting and Economics, 29(3), pp. 339-371.

Shnitser, N. (2010). A free pass for foreign firms? An assessment of SEC and private enforcement against foreign issuers. Yale Law Journal, pp. 1638-1701.

Siegel, J. (2005). Can foreign firms bond themselves effectively by renting US securities laws? Journal of Financial Economics, 75(2), pp. 319-359.

Silvers, R. (2016). The valuation impact of SEC enforcement actions on nontarget foreign firms. Journal of Accounting Research, 54(1), pp. 187-234.

Stein, J. C. (1989). Efficient capital markets, inefficient firms: A model of myopic corporate behavior. The Quarterly Journal of Economics, 104(4), pp. 655-669.

Stewart, J. B. (Producer). (2011). As a Watchdog Starves, Wall Street is Tossed a Bone. The New York Times. Retrieved from http://www.nytimes.com/2011/07/16/business/budget-cuts-to-sec-reduceits-effectiveness.html

Stulz, R. M. (1999). Globalization, corporate finance, and the cost of capital. Journal of Applied Corporate Finance, 12(3), pp. 8-25.

Teoh, S. H., Welch, I., \& Wong, T. J. (1998). Earnings management and the long-run market performance of initial public offerings. The Journal of Finance, 53(6), pp. 1935-1974.

Teoh, S. H., \& Wong, T. J. (2002). Why new issues and high-accrual firms underperform: The role of analysts' credulity. Review of Financial Studies, 15(3), pp. 869-900.

Venkataraman, R., Weber, J. P., \& Willenborg, M. (2008). Litigation risk, audit quality, and audit fees: Evidence from initial public offerings. The Accounting Review, 83(5), pp. 1315-1345.

Xu, D., \& Shenkar, O. (2002). Note: Institutional distance and the multinational enterprise. Academy of Management review, 27(4), pp. 608-618. 
Zaheer, S. (1995). Overcoming the liability of foreignness. Academy of Management Journal, 38(2), pp. 341-363. 
Table 1. Sample Description

Panel A: Sample Development

\begin{tabular}{|c|c|c|c|}
\hline & US & Foreign & Total \\
\hline All SDC Platinum US and foreign IPOs in years 1990-2009 & $\underline{4948}$ & $\underline{647}$ & $\underline{5595}$ \\
\hline \multicolumn{4}{|l|}{ Less observations: } \\
\hline For which prospectus not available & - & 136 & 136 \\
\hline With offering other than common/ordinary stock & - & 117 & 117 \\
\hline For financial services firms and utilities & $\underline{1498}$ & $\underline{19}$ & $\underline{1517}$ \\
\hline Initial sample & 3450 & 375 & 3825 \\
\hline $\begin{array}{l}\text { Insufficient financial data necessary for comparing abnormal } \\
\text { accruals in IPOs to mature US firms (Table 2) }\end{array}$ & $\underline{2427}$ & $\underline{34}$ & $\underline{2461}$ \\
\hline Sample used in mature US benchmark (Table 2) & 1023 & 341 & 1364 \\
\hline Insufficient data for control variables & $\underline{54}$ & $\underline{41}$ & $\underline{95}$ \\
\hline Sample with available controls & 969 & 300 & 1269 \\
\hline $\begin{array}{l}\text { Less than ten observations for year and industry matching } \\
\text { required to calculate abnormal accruals in IPO sample }\end{array}$ & 13 & 0 & 13 \\
\hline Final abnormal accruals IPO Sample & 956 & 300 & 1256 \\
\hline
\end{tabular}

Panel B: Sample Selection by Fama-French 12 Industry Classification

\begin{tabular}{llccc}
\hline & & US & Foreign & Total \\
FF1 & Consumer Non-Durables & 21 & 6 & 27 \\
FF2 & Consumer Durables & 14 & 5 & 19 \\
FF3 & Manufacturing & 52 & 21 & 73 \\
FF4 & Oil, Gas, and Coal Extraction and Products & 20 & 2 & 22 \\
FF5 & Chemicals and Allied Products & - & - & - \\
FF6 & Business Equipment & 366 & 143 & 509 \\
FF7 & Telephone and Television Transmission & 36 & 38 & 74 \\
FF8 & Utilities & - & - & - \\
FF9 & Wholesale, Retail, and Some Services & 89 & 7 & 96 \\
FF10 & Healthcare, Medical Equipment, and Drugs & 197 & 29 & 226 \\
FF11 & Finance & - & - & - \\
FF12 & Other & 161 & 49 & 210 \\
\hline Total & & $\mathbf{9 5 6}$ & $\mathbf{3 0 0}$ & $\mathbf{1 2 5 6}$ \\
\hline
\end{tabular}


Panel C: IPO Country of Origin by Period

\begin{tabular}{|c|c|c|c|c|c|c|}
\hline Country & 1990-1993 & 1994-1997 & 1998-2001 & 2002-2005 & 2006-2009 & Total \\
\hline Argentina & 0 & 0 & 3 & 0 & 1 & 4 \\
\hline Australia & 0 & 2 & 0 & 0 & 0 & 2 \\
\hline Belgium & 0 & 2 & 0 & 0 & 0 & 2 \\
\hline Brazil & 0 & 1 & 0 & 0 & 0 & 1 \\
\hline Canada & 3 & 9 & 12 & 2 & 3 & 29 \\
\hline China & 0 & 0 & 5 & 14 & 27 & 46 \\
\hline Denmark & 1 & 0 & 0 & 0 & 0 & 1 \\
\hline Finland & 0 & 1 & 0 & 0 & 0 & 1 \\
\hline France & 0 & 6 & 4 & 0 & 0 & 10 \\
\hline Germany & 0 & 2 & 5 & 0 & 0 & 7 \\
\hline Greece & 0 & 0 & 3 & 2 & 2 & 7 \\
\hline Hong Kong & 0 & 9 & 3 & 3 & 0 & 15 \\
\hline India & 0 & 0 & 2 & 0 & 0 & 2 \\
\hline Ireland & 0 & 4 & 5 & 0 & 2 & 11 \\
\hline Israel & 9 & 22 & 23 & 5 & 5 & 64 \\
\hline Italy & 1 & 3 & 1 & 1 & 0 & 6 \\
\hline Japan & 0 & 0 & 2 & 0 & 0 & 2 \\
\hline Mexico & 2 & 0 & 0 & 1 & 0 & 3 \\
\hline Netherlands & 2 & 14 & 4 & 0 & 1 & 21 \\
\hline New Zealand & 0 & 3 & 0 & 0 & 0 & 3 \\
\hline Norway & 0 & 0 & 1 & 0 & 0 & 1 \\
\hline Poland & 0 & 1 & 0 & 1 & 0 & 2 \\
\hline Singapore & 1 & 3 & 2 & 0 & 1 & 7 \\
\hline South-Korea & 0 & 1 & 3 & 3 & 1 & 8 \\
\hline Spain & 0 & 0 & 2 & 0 & 0 & 2 \\
\hline Sweden & 0 & 3 & 1 & 0 & 0 & 4 \\
\hline Switzerland & 0 & 3 & 3 & 1 & 0 & 7 \\
\hline UK & 2 & 18 & 10 & 2 & 0 & 32 \\
\hline US & 26 & 311 & 282 & 244 & 106 & 956 \\
\hline Total & 47 & 418 & 376 & 279 & 149 & 1256 \\
\hline
\end{tabular}

Notes: The table presents the sample selection process (Panel A), composition by industry (Panel B), composition by country and by period and country (Panel C). Panel A: Two observations are missing for INST further reducing the controls sample to 1276. We lose three further observations for incomplete panel when analyzing abnormal accruals in Tables 4 and 7. 
Table 2. Summary Statistics

Panel A: Summary Statistics of the Main Variables and Univariate Analysis Comparing Domestic and Foreign IPOs

\begin{tabular}{|c|c|c|c|c|c|c|c|c|c|c|c|c|c|c|c|c|c|c|}
\hline & \multicolumn{6}{|c|}{ Full Sample } & \multicolumn{6}{|c|}{ Domestic US IPOs } & \multicolumn{6}{|c|}{ Foreign IPOs } \\
\hline & $\mathbf{N}$ & Mean & STD & Q1 & Median & Q3 & $\mathbf{N}$ & Mean & STD & Q1 & Median & Q3 & $\mathbf{N}$ & Mean & STD & Q1 & Median & Q3 \\
\hline \multicolumn{19}{|c|}{ Mature US Firms benchmark } \\
\hline$A B N A C C$ & 1364 & -0.268 & 0.929 & -0.245 & -0.037 & 0.043 & 1023 & -0.323 & 0.997 & -0.287 & -0.050 & 0.031 & 341 & $-0.104^{* * *}$ & 0.662 & -0.125 & $-0.007^{* * *}$ & 0.118 \\
\hline \multicolumn{19}{|l|}{ IPO Sample } \\
\hline ABNACC & 1256 & -0.002 & 0.624 & -0.113 & 0.028 & 0.213 & 956 & -0.044 & 0.594 & -0.129 & 0.018 & 0.187 & 300 & $0.132^{* * *}$ & 0.697 & -0.078 & 0.068 & 0.317 \\
\hline FOREIGN & 1256 & 0.239 & 0.427 & 0.000 & 0.000 & 0.000 & 956 & 0.000 & 0.000 & 0.000 & 0.000 & 0.000 & 300 & $1.000^{* * *}$ & 0.000 & 1.000 & $1.000^{* * *}$ & 1.000 \\
\hline INST & 1256 & 0.896 & 0.306 & 1.000 & 1.000 & 1.000 & 956 & 1.000 & 0.000 & 1.000 & 1.000 & 1.000 & 300 & $0.563^{* * *}$ & 0.497 & 0.000 & $1.000^{* * *}$ & 1.000 \\
\hline MTB & 1103 & 0.160 & 0.327 & 0.025 & 0.063 & 0.149 & 803 & 0.117 & 0.189 & 0.024 & 0.060 & 0.123 & 300 & $0.275^{* * *}$ & 0.529 & 0.027 & $0.085^{* * *}$ & 0.233 \\
\hline HOME_ENF & 1256 & 39.755 & 10.423 & 39.000 & 39.000 & 53.000 & 956 & 43.657 & 6.600 & 39.000 & 39.000 & 53.000 & 300 & 27.320 & 10.632 & 18.000 & $26.500^{* * *}$ & 37.000 \\
\hline$S E C_{-} E N F$ & 300 & 0.016 & 0.015 & 0.007 & 0.008 & 0.027 & 0 & . & . & . & . & . & 300 & 0.016 & 0.015 & 0.007 & 0.008 & 0.027 \\
\hline PLIT & 270 & 2.493 & 1.465 & 2.100 & 2.260 & 3.230 & 0 & . & . & . & . & . & 270 & 2.493 & 1.465 & 2.100 & 2.260 & 3.230 \\
\hline LITIG & 1256 & 0.259 & 0.438 & 0.000 & 0.000 & 1.000 & 956 & 0.277 & 0.448 & 0.000 & 0.000 & 1.000 & 300 & $0.205^{* * *}$ & 0.401 & 0.000 & $0.000^{* * *}$ & 0.000 \\
\hline AUD & 1256 & 0.740 & 0.439 & 0.000 & 1.000 & 1.000 & 956 & 0.705 & 0.456 & 0.000 & 1.000 & 1.000 & 300 & $0.850^{* * *}$ & 0.354 & 1.000 & $1.000^{* * *}$ & 1.000 \\
\hline SOX & 1256 & 0.334 & 0.472 & 0.000 & 0.000 & 1.000 & 956 & 0.357 & 0.479 & 0.000 & 0.000 & 1.000 & 300 & $0.261^{* * *}$ & 0.441 & 0.000 & $0.000^{* * *}$ & 1.000 \\
\hline LTA & 1256 & 17.746 & 1.670 & 16.680 & 17.494 & 18.649 & 956 & 17.695 & 1.527 & 16.703 & 17.478 & 18.507 & 300 & $17.932^{* *}$ & 2.056 & 16.593 & 17.535 & 19.288 \\
\hline LPROC & 1256 & 18.051 & 1.025 & 17.500 & 18.048 & 18.594 & 956 & 17.968 & 0.905 & 17.485 & 17.978 & 18.489 & 300 & $18.300^{* * *}$ & 1.303 & 17.636 & $18.260^{* * *}$ & 19.071 \\
\hline НіТЕСН & 1256 & 0.486 & 0.500 & 0.000 & 0.000 & 1.000 & 956 & 0.449 & 0.498 & 0.000 & 0.000 & 1.000 & 300 & 0.204 & 0.489 & 0.000 & 1.000 & 1.000 \\
\hline$L E V$ & 1256 & 0.204 & 0.179 & 0.039 & 0.169 & 0.338 & 956 & 0.205 & 0.178 & 0.042 & 0.169 & 0.338 & 300 & $0.599^{* * *}$ & 0.184 & 0.034 & $0.161^{* * *}$ & 0.339 \\
\hline LSALES & 1256 & 16.888 & 3.828 & 16.174 & 17.406 & 18.683 & 956 & 16.761 & 4.039 & 16.154 & 17.418 & 18.687 & 300 & $17.295^{* *}$ & 3.029 & 16.190 & 17.385 & 18.617 \\
\hline CFO & 1256 & -0.363 & 1.392 & -0.461 & 0.038 & 0.185 & 956 & -0.431 & 1.410 & -0.594 & 0.021 & 0.169 & 300 & $-0.147^{* * *}$ & 1.313 & -0.165 & $0.074^{* * *}$ & 0.218 \\
\hline LROA & 1256 & -0.339 & 0.813 & -0.473 & -0.031 & 0.065 & 956 & -0.389 & 0.832 & -0.570 & -0.073 & 0.052 & 300 & $-0.180^{* * *}$ & 0.730 & -0.126 & $0.012^{* * *}$ & 0.112 \\
\hline
\end{tabular}


Panel B: Summary Statistics of Foreign IPOs and a Univariate Analysis Comparing Weak and Strong Home Institutions using Leuz's (2010) Classification

\begin{tabular}{|c|c|c|c|c|c|c|c|c|c|c|c|c|}
\hline & \multicolumn{6}{|c|}{ Weak Home Institutions } & \multicolumn{6}{|c|}{ Strong Home Institutions } \\
\hline & $\mathbf{N}$ & Mean & STD & Q1 & Median & Q3 & $\mathbf{N}$ & Mean & STD & Q1 & Median & Q3 \\
\hline ABNACC & 131 & 0.036 & 0.418 & -0.100 & 0.032 & 0.280 & 169 & $0.206^{* *}$ & 0.847 & -0.051 & $0.089^{*}$ & 0.340 \\
\hline MTB & 131 & 0.295 & 0.594 & 0.016 & 0.060 & 0.200 & 169 & 0.258 & 0.475 & 0.035 & 0.098 & 0.264 \\
\hline HOME_ENF & 131 & 26.435 & 10.483 & 16.000 & 28.000 & 37.000 & 169 & 28.006 & 10.727 & 18.000 & 24.000 & 38.000 \\
\hline$S E C \_E N F$ & 131 & 0.027 & 0.017 & 0.018 & 0.027 & 0.027 & 169 & $0.008^{* * *}$ & 0.004 & 0.007 & $0.007^{* * *}$ & 0.008 \\
\hline PLIT & 130 & 3.151 & 1.777 & 2.730 & 3.230 & 3.990 & 140 & $1.882^{* * *}$ & 0.666 & 1.790 & $2.100^{* * *}$ & 2.260 \\
\hline LITIG & 131 & 0.221 & 0.417 & 0.000 & 0.000 & 0.000 & 169 & 0.174 & 0.388 & 0.000 & 0.000 & 0.000 \\
\hline AUD & 131 & 0.916 & 0.278 & 1.000 & 1.000 & 1.000 & 169 & $0.796^{* * *}$ & 0.398 & 1.000 & $1.000^{* * *}$ & 1.000 \\
\hline SOX & 131 & 0.405 & 0.493 & 0.000 & 0.000 & 1.000 & 169 & $0.144^{* * *}$ & 0.362 & 0.000 & $0.000^{* * *}$ & 0.000 \\
\hline LTA & 131 & 18.654 & 1.856 & 17.301 & 18.210 & 19.654 & 169 & $17.326^{* * *}$ & 2.023 & 16.157 & $16.983^{* * *}$ & 18.334 \\
\hline LPROC & 131 & 18.793 & 1.206 & 18.156 & 18.610 & 19.349 & 169 & $17.911^{* * *}$ & 1.256 & 17.148 & $17.906^{* * *}$ & 18.579 \\
\hline НіТЕСН & 131 & 0.221 & 0.177 & 0.082 & 0.196 & 0.341 & 169 & $0.671^{* *}$ & 0.189 & 0.015 & $0.127^{* *}$ & 0.338 \\
\hline$L E V$ & 131 & 0.519 & 0.502 & 0.000 & 1.000 & 1.000 & 169 & 0.194 & 0.470 & 0.000 & $1.000^{* * *}$ & 1.000 \\
\hline LSALES & 131 & 18.220 & 2.175 & 16.970 & 18.003 & 19.279 & 169 & $16.579^{* * *}$ & 3.389 & 15.833 & $17.000^{* * *}$ & 17.911 \\
\hline CFO & 131 & 0.070 & 0.839 & -0.076 & 0.098 & 0.258 & 169 & $-0.273^{* *}$ & 1.568 & -0.274 & $0.029^{* * *}$ & 0.207 \\
\hline LROA & 131 & -0.035 & 0.335 & -0.039 & 0.027 & 0.116 & 169 & $-0.270^{* * *}$ & 0.912 & -0.262 & $-0.003^{* *}$ & 0.111 \\
\hline
\end{tabular}


Notes: The table presents the descriptive statistics for the full sample as well as for distinguishing between domestic US IPOs and foreign IPOs. Panel A reports the descriptive statistics for the variables used in the main tests. Panel B reports the differences between IPOs from strong (INST $=1$ ) and weak (INST=0) home institutions within the foreign subsample. INST is an indicator variable that is set equal to 1 if the IPO firm comes from a country that is classified by Leuz (2010) as belonging to the first cluster in Panel C of Table 3 (i.e., regarded as having the strongest institutions); zero otherwise. The results of tests for the differences in the means and medians (the latter using Wilcoxon rank-test) are reported under the Foreign IPOs block (in Panels A) and the Strong Home Institutions block (in Panel B). ${ }^{*},{ }^{* *},{ }^{* * *}$ denote differences that are significant at the $10 \%, 5 \%$, and $1 \%$ levels, respectively. See the Appendix for variable definitions. 
Table 3. Correlations Matrix

\begin{tabular}{|c|c|c|c|c|c|c|c|c|c|c|c|c|c|c|c|c|}
\hline & 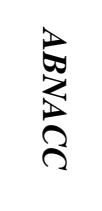 & 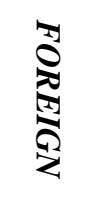 & 岕 & $\frac{3}{D}$ & 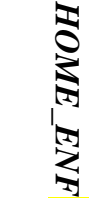 & 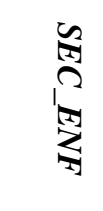 & $\underset{7}{7}$ & $\mathbb{S}$ & $\stackrel{\infty}{\varnothing}$ & $\stackrel{5}{\stackrel{N}{*}}$ & 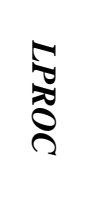 & $\underset{\infty}{\infty}$ & Tิ & D్ర & $\stackrel{7}{D}$ & $\stackrel{\nabla}{\nabla}$ \\
\hline FOREIGN & 0.12 & & & & & & & & & & & & & & & \\
\hline INST & -0.02 & -0.62 & & & & & & & & & & & & & & \\
\hline MTA & -0.03 & 0.21 & -0.15 & & & & & & & & & & & & & \\
\hline HOME_ENF & -0.07 & -0.67 & 0.43 & -0.12 & & & & & & & & & & & & \\
\hline$S E C \_E N F$ & -0.12 & - & -0.63 & 0.01 & 0.21 & & & & & & & & & & & \\
\hline PLIT & -0.09 & -0.70 & -0.43 & -0.01 & 0.26 & 0.62 & & & & & & & & & & \\
\hline AUD & 0.08 & 0.14 & -0.14 & 0.02 & 0.03 & 0.02 & -0.07 & & & & & & & & & \\
\hline SOX & 0.00 & -0.09 & -0.05 & -0.01 & 0.60 & 0.11 & 0.18 & -0.05 & & & & & & & & \\
\hline$L E V$ & -0.01 & 0.00 & -0.03 & 0.02 & -0.03 & 0.11 & -0.01 & -0.13 & -0.05 & & & & & & & \\
\hline LPROC & 0.00 & 0.14 & -0.25 & 0.12 & -0.13 & 0.28 & 0.13 & -0.08 & 0.20 & 0.13 & & & & & & \\
\hline LSALES & 0.03 & 0.06 & -0.12 & -0.17 & -0.13 & 0.23 & 0.04 & -0.11 & -0.01 & 0.20 & 0.33 & & & & & \\
\hline CFO & 0.05 & 0.10 & -0.11 & -0.25 & -0.04 & 0.07 & 0.07 & -0.01 & 0.11 & -0.03 & 0.15 & 0.38 & & & & \\
\hline LROA & 0.16 & 0.12 & -0.13 & -0.29 & -0.10 & 0.15 & 0.06 & -0.01 & 0.03 & -0.03 & 0.16 & 0.40 & 0.75 & & & \\
\hline LTA & 0.04 & 0.06 & -0.19 & -0.30 & -0.08 & 0.21 & 0.05 & -0.10 & 0.18 & 0.23 & 0.69 & 0.50 & 0.29 & 0.36 & & \\
\hline LITIG & -0.01 & -0.08 & 0.03 & 0.03 & 0.15 & -0.01 & 0.06 & 0.05 & 0.13 & -0.10 & -0.06 & -0.20 & -0.07 & -0.11 & -0.05 & \\
\hline НіТЕСН & 0.01 & 0.13 & -0.03 & 0.12 & -0.16 & -0.20 & 0.01 & 0.00 & -0.12 & -0.12 & 0.00 & 0.05 & -0.03 & -0.04 & -0.11 & -0.15 \\
\hline
\end{tabular}

Note: The table presents Pearson pair-wise correlations for selected variables. Correlations equal or above 0.08 and equal or below -0.08 are significant at the 5\% level. Correlations for SEC_ENF and PLIT are calculated within the foreign IPOs subsample. See the Appendix for variable definitions. 
Table 4. Panel A - Enforcement and Litigation Regressions

\begin{tabular}{|c|c|c|c|c|c|c|}
\hline \multirow[t]{3}{*}{ Dependent variable: } & \multicolumn{3}{|c|}{$S E C \_E N F$} & \multicolumn{3}{|c|}{ PLIT } \\
\hline & \multicolumn{2}{|c|}{ (1) } & (2) & (3) & & 4) \\
\hline & \multicolumn{2}{|c|}{ By Firm } & By Country & By Firm & \multicolumn{2}{|c|}{ By Country } \\
\hline \multirow[t]{2}{*}{ CONSTANT } & \multirow{2}{*}{\multicolumn{2}{|c|}{$\begin{array}{c}-0.005 \\
(0.615)\end{array}$}} & -0.005 & $1.664^{* * *}$ & \multicolumn{2}{|c|}{0.104} \\
\hline & & & $(0.510)$ & $(0.002)$ & \multicolumn{2}{|c|}{$(0.901)$} \\
\hline \multirow[t]{2}{*}{ INST } & \multicolumn{2}{|c|}{$-0.018^{* * *}$} & $-0.013^{* *}$ & $-1.223^{* * *}$ & \multirow{2}{*}{\multicolumn{2}{|c|}{$\begin{array}{c}-0.874 \\
(0.133)\end{array}$}} \\
\hline & \multicolumn{2}{|c|}{$(0.000)$} & $(0.029)$ & $(0.000)$ & & \\
\hline \multirow[t]{2}{*}{$A G G \_E M$} & \multirow{2}{*}{\multicolumn{2}{|c|}{$\begin{array}{c}\mathbf{0 . 0 0 1}^{* * *} \\
(0.002)\end{array}$}} & 0.001 & $0.037^{* *}$ & \multicolumn{2}{|c|}{0.045} \\
\hline & & & $(0.000)$ & $(0.011)$ & \multicolumn{2}{|c|}{$(0.242)$} \\
\hline GDP & \multicolumn{2}{|c|}{$0.543^{* *}$} & & $18.643^{* * *}$ & & \\
\hline & (0. & & & $(0.000)$ & & \\
\hline$G D P \_A v$ & & & $0.610^{* *}$ & & & .027 \\
\hline & & & $(0.029)$ & & & 113) \\
\hline$N$ & & & 28 & 270 & & 26 \\
\hline$R^{2}$ & & & 0.303 & 0.197 & & 187 \\
\hline Panel B - Signed & normal A & ruals, SE & C Enforcem & nd Private $\mathbf{L}$ & itigation & \\
\hline Dependent variable: $\boldsymbol{A B N A C C}$ & SEC E & orcemen & Actions & Priv & ate Litiga & \\
\hline & $(1)$ & (2) & (3) & $(4)$ & (5) & $(6)$ \\
\hline & Foreign & Strong & Weak & Foreign & Strong & Weak \\
\hline & Sample & Sample & Sample & Sample & Sample & Sample \\
\hline CONSTANT & 0.871 & 1.125 & -0.639 & 0.736 & 1.736 & -0.766 \\
\hline & $(0.141)$ & $(0.278)$ & $(0.262)$ & $(0.356)$ & $(0.202)$ & $(0.145)$ \\
\hline Main test variable (THREAT) & & & & & & \\
\hline$\overline{S E C \_E N F}$ & $-3.572^{* *}$ & 9.623 & $-6.334^{*}$ & & & \\
\hline & $(0.011)$ & $(0.146)$ & $(0.057)$ & & & \\
\hline PLIT & & & & $-0.031^{* *}$ & 0.015 & $-0.063^{*}$ \\
\hline & & & & $(0.024)$ & $(0.719)$ & $(0.078)$ \\
\hline Variables capturing other sour & of scrutin & & & & & \\
\hline LITIG & 0.053 & 0.014 & 0.019 & 0.074 & 0.104 & 0.085 \\
\hline & $(0.612)$ & $(0.951)$ & $(0.750)$ & $(0.123)$ & $(0.330)$ & $(0.244)$ \\
\hline$A U D$ & $-0.147^{* *}$ & -0.146 & $-0.154^{*}$ & $-0.142^{* *}$ & -0.091 & $-0.200^{* *}$ \\
\hline & $(0.034)$ & $(0.215)$ & $(0.083)$ & $(0.026)$ & $(0.590)$ & $(0.045)$ \\
\hline SOX & $-0.612^{* * *}$ & 0.382 & -0.173 & -0.274 & $0.407^{* * *}$ & 0.113 \\
\hline & $(0.010)$ & $(0.145)$ & $(0.444)$ & $(0.147)$ & $(0.003)$ & $(0.703)$ \\
\hline LTA & 0.046 & 0.075 & 0.015 & 0.037 & 0.068 & 0.024 \\
\hline & $(0.302)$ & $(0.356)$ & $(0.799)$ & $(0.203)$ & $(0.150)$ & $(0.672)$ \\
\hline Variables capturing incentives & nflate ear & & & & & \\
\hline LPROC & -0.037 & -0.108 & 0.015 & -0.068 & -0.197 & 0.016 \\
\hline & $(0.574)$ & $(0.376)$ & $(0.743)$ & $(0.378)$ & $(0.155)$ & $(0.692)$ \\
\hline НITECH & $-0.181^{*}$ & -0.092 & $-0.414^{* * *}$ & $-0.159^{* *}$ & -0.095 & $-0.370^{* * *}$ \\
\hline & $(0.058)$ & $(0.528)$ & $(0.005)$ & $(0.025)$ & $(0.536)$ & $(0.000)$ \\
\hline$L E V$ & 0.063 & 0.121 & -0.191 & $-0.179^{*}$ & -0.126 & -0.359 \\
\hline & $(0.663)$ & $(0.674)$ & $(0.598)$ & $(0.086)$ & $(0.583)$ & $(0.320)$ \\
\hline Other control variables & & & & & & \\
\hline LSALES & -0.022 & -0.031 & 0.038 & 0.010 & 0.041 & 0.025 \\
\hline & $(0.593)$ & $(0.607)$ & $(0.512)$ & $(0.525)$ & $(0.177)$ & $(0.669)$ \\
\hline CFO & -0.036 & 0.036 & -0.135 & -0.045 & 0.028 & -0.128 \\
\hline & $(0.339)$ & $(0.499)$ & $(0.155)$ & $(0.326)$ & $(0.645)$ & $(0.136)$ \\
\hline LROA & -0.149 & -0.289 & $0.262^{* *}$ & -0.158 & -0.339 & $0.239^{* *}$ \\
\hline & $(0.334)$ & $(0.249)$ & $(0.029)$ & $(0.322)$ & $(0.138)$ & $(0.024)$ \\
\hline Year and industry $F E$ & Yes & Yes & Yes & Yes & Yes & Yes \\
\hline$N$ & 300 & 169 & 131 & 270 & 140 & 130 \\
\hline $\operatorname{Adj} R^{2}$ & 0.040 & 0.011 & 0.144 & 0.037 & 0.001 & 0.141 \\
\hline
\end{tabular}


Notes: The table presents results of the regression models of SEC enforcement and private litigation. Panel A presents the estimation results for Models 3a and 3b-i.e., SEC enforcement and private litigation, respectively. Columns 1 and 3 include all 300 foreign IPOs and columns 2 and 4 are at the country level. Panel B presents results of the regression models of signed abnormal accruals with the variables of interest being SEC enforcement (SEC_ENF) and private litigation (PLIT) in columns (1)(3) and Columns (4)-(6), respectively. Columns (1) and (4) present regression results for Model 4 for the whole sample of foreign firms. Columns (2) and (5) present regression for Model 4 for IPOs from strong institutions while columns (3) and (6) present regression for Model 4 for IPOs from weak institutions while Columns (3) and (6). p-values based on standard errors corrected for heteroskedasticity and clustering at the industry level are reported in parentheses below the coefficient estimates. ${ }^{* * *},{ }^{* * *}$ indicate significance at the two-tailed 10\%, 5\%, and 1\% levels, respectively. See the Appendix for variable definitions. 
Table 5. Signed Abnormal Accruals, IPO Foreignness, and Home Institutions

Dependent variable: $\boldsymbol{A B N A C C}$

\begin{tabular}{|c|c|c|c|c|c|}
\hline & \multirow[b]{2}{*}{$\begin{array}{c}\text { (1) } \\
\text { Foreign } \\
\text { Sample }\end{array}$} & \multirow[b]{2}{*}{$\begin{array}{c}\text { (2) } \\
\text { Full Sample }\end{array}$} & \multirow[b]{2}{*}{$\begin{array}{c}\text { (3) } \\
\text { Full Sample }\end{array}$} & \multirow[b]{2}{*}{$\begin{array}{c}(4) \\
\text { Strong + US }\end{array}$} & \multirow[b]{2}{*}{$\begin{array}{c}\text { (5) } \\
\text { Weak + US }\end{array}$} \\
\hline & & & & & \\
\hline CONSTANT & $\begin{array}{c}0.647 \\
(0.219)\end{array}$ & $\begin{array}{c}0.043 \\
(0.866)\end{array}$ & $\begin{array}{c}-0.101 \\
(0.684)\end{array}$ & $\begin{array}{c}-0.003 \\
(0.993)\end{array}$ & $\begin{array}{c}-0.448 \\
(0.141)\end{array}$ \\
\hline \multicolumn{6}{|l|}{ Main test variables } \\
\hline$\overline{\text { FOREIGN }}$ & & $\begin{array}{l}0.181^{* *} \\
(0.035)\end{array}$ & $\begin{array}{c}0.030 \\
(0.547)\end{array}$ & $\begin{array}{l}0.285^{* * *} \\
(0.009)\end{array}$ & $\begin{array}{c}-0.014 \\
(0.732)\end{array}$ \\
\hline FOREIGN_STRONG_INST & & & $\begin{array}{c}0.260 * * * \\
(0.000)\end{array}$ & & \\
\hline INST & $\begin{array}{l}0.102^{* *} \\
(0.039)\end{array}$ & & & & \\
\hline \multicolumn{6}{|c|}{ Variables capturing other sources of scrutiny } \\
\hline LITIG & $\begin{array}{c}0.031 \\
(0.763)\end{array}$ & $\begin{array}{c}-0.009 \\
(0.902)\end{array}$ & $\begin{array}{c}-0.006 \\
(0.925)\end{array}$ & $\begin{array}{c}-0.008 \\
(0.913)\end{array}$ & $\begin{array}{c}0.016 \\
(0.826)\end{array}$ \\
\hline AUD & $\begin{array}{l}-0.137^{*} \\
(0.065)\end{array}$ & $\begin{array}{l}0.103^{* *} \\
(0.035)\end{array}$ & $\begin{array}{l}0.119 * * \\
(0.021)\end{array}$ & $\begin{array}{l}0.117^{* *} \\
(0.019)\end{array}$ & $\begin{array}{l}0.148^{* * *} \\
(0.003)\end{array}$ \\
\hline SOX & $\begin{array}{c}-0.518^{* *} \\
(0.026)\end{array}$ & $\begin{array}{c}-0.048 \\
(0.675)\end{array}$ & $\begin{array}{l}-0.145 \\
(0.116)\end{array}$ & $\begin{array}{l}0.175^{* *} \\
(0.041)\end{array}$ & $\begin{array}{l}-0.072 \\
(0.497)\end{array}$ \\
\hline LTA & $\begin{array}{c}0.055 \\
(0.256)\end{array}$ & $\begin{array}{c}0.015 \\
(0.304)\end{array}$ & $\begin{array}{c}0.019 \\
(0.218)\end{array}$ & $\begin{array}{c}0.011 \\
(0.503)\end{array}$ & $\begin{array}{l}0.034^{* *} \\
(0.032)\end{array}$ \\
\hline \multicolumn{6}{|c|}{ Variables capturing incentives to inflate earnings } \\
\hline LPROC & $\begin{array}{c}-0.042 \\
(0.496)\end{array}$ & $\begin{array}{l}-0.030 \\
(0.344)\end{array}$ & $\begin{array}{c}-0.019 \\
(0.511)\end{array}$ & $\begin{array}{c}-0.018 \\
(0.609)\end{array}$ & $\begin{array}{c}-0.019 \\
(0.474)\end{array}$ \\
\hline HiTECH & $\begin{array}{l}-0.217^{*} \\
(0.056)\end{array}$ & $\begin{array}{c}0.031 \\
(0.707)\end{array}$ & $\begin{array}{c}0.028 \\
(0.709)\end{array}$ & $\begin{array}{c}0.044 \\
(0.524)\end{array}$ & $\begin{array}{c}0.005 \\
(0.951)\end{array}$ \\
\hline$L E V$ & $\begin{array}{c}0.002 \\
(0.992)\end{array}$ & $\begin{array}{c}0.056 \\
(0.481)\end{array}$ & $\begin{array}{c}0.064 \\
(0.437)\end{array}$ & $\begin{array}{c}0.043 \\
(0.506)\end{array}$ & $\begin{array}{l}-0.062 \\
(0.410)\end{array}$ \\
\hline \multicolumn{6}{|l|}{ Other control variables } \\
\hline$\overline{L S A L E S}$ & $\begin{array}{c}-0.022 \\
(0.585)\end{array}$ & $\begin{array}{l}-0.002 \\
(0.772)\end{array}$ & $\begin{array}{l}-0.001 \\
(0.847)\end{array}$ & $\begin{array}{c}-0.001 \\
(0.863)\end{array}$ & $\begin{array}{c}0.001 \\
(0.763)\end{array}$ \\
\hline CFO & $\begin{array}{c}-0.044 \\
(0.250)\end{array}$ & $\begin{array}{c}-0.079^{* *} \\
(0.026)\end{array}$ & $\begin{array}{c}-0.081^{* *} \\
(0.024)\end{array}$ & $\begin{array}{c}-0.078^{* *} \\
(0.036)\end{array}$ & $\begin{array}{c}-0.095^{* *} \\
(0.013)\end{array}$ \\
\hline LROA & $\begin{array}{l}-0.179 \\
(0.296)\end{array}$ & $\begin{array}{l}0.221^{* *} \\
(0.024)\end{array}$ & $\begin{array}{c}0.222 * * \\
(0.021)\end{array}$ & $\begin{array}{l}0.222^{* *} \\
(0.023)\end{array}$ & $\begin{array}{l}0.300^{* * *} \\
(0.000)\end{array}$ \\
\hline Year and industry $F E$ & Yes & Yes & YES & Yes & Yes \\
\hline$N$ & 300 & 1256 & 1256 & 1123 & 1089 \\
\hline $\operatorname{Adj} R^{2}$ & 0.036 & 0.040 & 0.048 & 0.042 & 0.092 \\
\hline
\end{tabular}

Notes: The table presents results of the regression models of signed abnormal accruals. Column (1) presents regression results for Model 5 using only the foreign subsample. Columns (2) and (3) present regression results for Model 5 for the full sample. Columns (4) and (5) present regression results for Model 5 for the sample of US IPOs and foreign IPOs from strong or weak institutions, respectively. $p$-values based on standard errors corrected for heteroskedasticity and clustering at the industry level are reported in parentheses below the coefficient estimates. ${ }^{* * * * *}$, indicate significance at the two tailed $10 \%$, $5 \%$, and $1 \%$ levels, respectively. See the Appendix for variable definitions. 
Table 6. Self-selection Regression

Dependent variable:

Panel A: Probit Regression

Probability of US Listing

\begin{tabular}{|c|c|c|c|c|c|}
\hline CONSTANT & $\begin{array}{l}-3.969^{* * *} \\
(0.000)\end{array}$ & $\begin{array}{l}-6.555^{* * *} \\
(0.000)\end{array}$ & $\begin{array}{l}-5.66^{* * *} \\
(0.000)\end{array}$ & $\begin{array}{l}-6.918^{* * *} \\
(0.000)\end{array}$ & $\begin{array}{l}-7.033^{* * *} \\
(0.000)\end{array}$ \\
\hline LTA & $\begin{array}{l}0.0966^{* * *} \\
(0.001)\end{array}$ & $\begin{array}{l}0.097^{* * *} \\
(0.001)\end{array}$ & $\begin{array}{l}0.84^{* * *} \\
(0.005)\end{array}$ & $\begin{array}{l}0.094^{* * *} \\
(0.000)\end{array}$ & $\begin{array}{l}0.097^{* * *} \\
(0.000)\end{array}$ \\
\hline LPROC & $\begin{array}{l}0.194^{* * *} \\
(0.000)\end{array}$ & $\begin{array}{l}0.207^{* * * *} \\
(0.001)\end{array}$ & $\begin{array}{l}0.220^{* * * *} \\
(0.000)\end{array}$ & $\begin{array}{l}0.221^{* * * *} \\
(0.000)\end{array}$ & $\begin{array}{l}0.223^{* * *} \\
(0.000)\end{array}$ \\
\hline$A G G \_E M$ & $\begin{array}{c}0.004 \\
(0.504)\end{array}$ & $\begin{array}{l}0.037^{* * *} \\
(0.000)\end{array}$ & $\begin{array}{l}0.147^{*} \\
(0.051)\end{array}$ & $\begin{array}{l}0.040^{* * *} \\
(0.000)\end{array}$ & $\begin{array}{l}0.039^{* * * *} \\
(0.000)\end{array}$ \\
\hline HOME_ENF & $\begin{array}{l}0.039^{* * *} \\
(0.000)\end{array}$ & & & & $\begin{array}{l}0.005 \\
(0.435)\end{array}$ \\
\hline$S E C \_E N F$ & & $\begin{array}{l}0.097^{* * *} \\
(0.000)\end{array}$ & & $\begin{array}{l}0.095^{* * *} \\
(0.000)\end{array}$ & $\begin{array}{l}0.086^{* * *} \\
(0.000)\end{array}$ \\
\hline PLIT & & & $\begin{array}{c}0.021 \\
(0.446)\end{array}$ & $\begin{array}{l}-0.011 \\
(0.699)\end{array}$ & $\begin{array}{l}-0.123 \\
(0.655)\end{array}$ \\
\hline HITECH & $\begin{array}{l}0.407^{* * *} \\
(\mathbf{0 . 0 0 0 )}\end{array}$ & $\begin{array}{l}0.463^{* * *} \\
(0.000)\end{array}$ & $\begin{array}{l}0.464^{* * *} \\
(0.000)\end{array}$ & $\begin{array}{l}0.486^{* * *} \\
(0.000)\end{array}$ & $\begin{array}{l}0.486^{* * *} \\
(0.000)\end{array}$ \\
\hline GDP & $\begin{array}{c}-46.588^{* * *} \\
(0.000)\end{array}$ & $\begin{array}{c}-39.601^{* * *} \\
(0.000)\end{array}$ & $\begin{array}{c}-38.748^{* * *} \\
(0.000)\end{array}$ & $\begin{array}{c}-37.236^{* * *} \\
(\mathbf{0 . 0 0 0 )}\end{array}$ & $\begin{array}{c}-38.750^{* * *} \\
(0.000)\end{array}$ \\
\hline $\begin{array}{l}N \\
\text { Pseudo } R^{2}\end{array}$ & $\begin{array}{l}1696 \\
0.327 \\
\end{array}$ & $\begin{array}{l}1696 \\
0.354 \\
\end{array}$ & $\begin{array}{l}1564 \\
0.325 \\
\end{array}$ & $\begin{array}{l}1564 \\
0.344 \\
\end{array}$ & $\begin{array}{l}1564 \\
0.344 \\
\end{array}$ \\
\hline \multicolumn{6}{|c|}{ Panel B -Signed Abnormal Accruals, INST, and Inverse Mills Ratio } \\
\hline $\begin{array}{l}\text { Dependent variable: } \\
\text { ABNACC }\end{array}$ & (1) & (2) & (3) & (4) & (5) \\
\hline CONSTANT & $\begin{array}{l}\mathbf{0 . 7 0 7}^{* *} \\
(0.047)\end{array}$ & $\begin{array}{c}0.663 \\
(0.152)\end{array}$ & $\begin{array}{c}0.368 \\
(0.578)\end{array}$ & $\begin{array}{l}0.501 \\
0.486\end{array}$ & $\begin{array}{c}0.492 \\
(0.480)\end{array}$ \\
\hline Main test variables & & & & & \\
\hline$\overline{I N S T}$ & $\begin{array}{l}0.105^{*} \\
(0.075)\end{array}$ & $\begin{array}{l}0^{.103} \\
(0.070)\end{array}$ & $\begin{array}{c}0.135^{*} \\
(0.089)\end{array}$ & $\begin{array}{l}0.147^{* *} \\
(0.047)\end{array}$ & $\begin{array}{l}0.146^{*} \\
(0.051)\end{array}$ \\
\hline IMR & $\begin{array}{c}-0.018 \\
(0.845)\end{array}$ & $\begin{array}{c}-0.009 \\
(0.890)\end{array}$ & $\begin{array}{c}0.023 \\
(0817)\end{array}$ & $\begin{array}{l}-0.037 \\
(0.574)\end{array}$ & $\begin{array}{c}-0.290 \\
(0.664)\end{array}$ \\
\hline Controls & Yes & Yes & Yes & Yes & Yes \\
\hline Year and industry $F E$ & Yes & Yes & Yes & Yes & Yes \\
\hline $\begin{array}{l} \\
{\text { Adi } R^{2}}^{2}\end{array}$ & $\begin{array}{c}300 \\
0.036\end{array}$ & $\begin{array}{c}296 \\
0033\end{array}$ & $\begin{array}{c}266 \\
0035\end{array}$ & $\begin{array}{c}266 \\
0.035\end{array}$ & $\begin{array}{c}266 \\
0.034\end{array}$ \\
\hline
\end{tabular}

Notes: The table presents results of the regression models of signed abnormal accruals using a Heckman two-stage selection model to address potential selection bias concerns. Panel A presents the binary probit estimation results for US listings (IPOs in the US, or in the US and home country, are assigned the value 1, while IPOs conducted exclusively in firm's foreign country are assigned 0). Columns (1)-(3) present the results with the inclusion of home enforcement measure (HOME_ENF), SEC enforcement (SEC_ENF) and private litigation (PLIT), respectively. Column (4) presents the results with the inclusion of both enforcement (SEC_ENF) and private litigation (PLIT). Column (5) presents the results with the inclusion of home enforcement measure (HOME_ENF), SEC enforcement (SEC_ENF) and private litigation (PLIT) together. Panel B presents results of the regression Model 5 of signed abnormal accruals with the inclusion of the inverse mills ratio (IMR) estimated in step 1 (Panel A). Columns (1)-(5) correspond to the estimation specifications reported in Columns (1)-(5) in Panel A. For brevity, we report only the coefficients on INST and IMR in Panel B. $p$-values based on standard errors corrected for heteroskedasticity and clustering at the industry level are reported in parentheses below the coefficient estimates. ${ }^{* * *},{ }^{* * * *}$ indicate significance at the two-tailed $10 \%, 5 \%$, and $1 \%$ levels, respectively. See the Appendix for variable definitions. 
Table 7. Analysis of IPO Market Values

\begin{tabular}{|c|c|c|c|c|}
\hline \multirow[t]{3}{*}{ Dependent variable: $\boldsymbol{M T A}$} & & & & \\
\hline & (1) & (2) & (3) & (4) \\
\hline & $\begin{array}{l}\text { Foreign } \\
\text { Sample }\end{array}$ & Full Sample & Strong + US & Weak + US \\
\hline CONSTANT & $\begin{array}{l}2.151^{* * * *} \\
(0.000)\end{array}$ & $\begin{array}{l}1.047^{* * *} \\
(0.000)\end{array}$ & $\begin{array}{l}\mathbf{0 . 8 9 0}^{* * * *} \\
(0.000)\end{array}$ & $\begin{array}{l}1.155^{* * *} \\
(0.000)\end{array}$ \\
\hline \multicolumn{5}{|l|}{ Main test variables } \\
\hline$A B N A C C$ & $\begin{array}{l}-0.033 \\
(0.459)\end{array}$ & $\begin{array}{c}-0.012 \\
(0.407)\end{array}$ & $\begin{array}{c}-0.002 \\
(0.905)\end{array}$ & $\begin{array}{c}-0.001 \\
(0.956)\end{array}$ \\
\hline FOREIGN & & $\begin{array}{l}0.205^{* * *} \\
(\mathbf{0 . 0 0 0 )}\end{array}$ & $\begin{array}{l}0.128^{* * * *} \\
(0.000)\end{array}$ & $\begin{array}{l}0.318^{* * * *} \\
(\mathbf{0 . 0 0 0 )}\end{array}$ \\
\hline INST & $\begin{array}{c}-0.182^{* * *} \\
(0.008)\end{array}$ & & & \\
\hline \multicolumn{5}{|l|}{ Control variables } \\
\hline LITIG & $\begin{array}{l}0.266^{* * *} \\
(0.006)\end{array}$ & $\begin{array}{c}0.049^{*} \\
(0.054)\end{array}$ & $\begin{array}{c}0.004 \\
(0.848)\end{array}$ & $\begin{array}{c}0.037 \\
(0.103)\end{array}$ \\
\hline AUD & $\begin{array}{l}0.202^{* * * *} \\
(0.001)\end{array}$ & $\begin{array}{l}0.094^{* * *} \\
(0.000)\end{array}$ & $\begin{array}{l}0.055^{* * * *} \\
(0.009)\end{array}$ & $\begin{array}{l}\mathbf{0 . 0 7 1}^{* * * *} \\
(\mathbf{0 . 0 0 1 )}\end{array}$ \\
\hline SOX & $\begin{array}{c}-0.124 \\
(0.551)\end{array}$ & $\begin{array}{c}-0.147^{* * *} \\
(0.002)\end{array}$ & $\begin{array}{c}0.040 \\
(0.576)\end{array}$ & $\begin{array}{l}-0.057 \\
(0.215)\end{array}$ \\
\hline LTA & $\begin{array}{c}-0.145^{* * *} \\
(0.000)\end{array}$ & $\begin{array}{c}-0.087^{* * *} \\
(0.000)\end{array}$ & $\begin{array}{c}-\mathbf{- 0 . 0 6 8}^{* * *} \\
(0.000)\end{array}$ & $\begin{array}{c}-0.095^{* * *} \\
(0.000)\end{array}$ \\
\hline НITECH & $\begin{array}{l}0.348^{* * *} \\
(0.008)\end{array}$ & $\begin{array}{c}0.045 \\
(0.181)\end{array}$ & $\begin{array}{c}0.003 \\
(0.913)\end{array}$ & $\begin{array}{c}0.013 \\
(0.720)\end{array}$ \\
\hline$L E V$ & $\begin{array}{c}0.128 \\
(0.518)\end{array}$ & $\begin{array}{l}0.148^{*} \\
(0.050)\end{array}$ & $\begin{array}{l}0.134^{*} \\
(0.055)\end{array}$ & $\begin{array}{c}0.112 \\
(0.120)\end{array}$ \\
\hline LSALES & $\begin{array}{c}0.015 \\
(0.180)\end{array}$ & $\begin{array}{c}0.002 \\
(0.572)\end{array}$ & $\begin{array}{l}-0.002 \\
(0.475)\end{array}$ & $\begin{array}{c}0.000 \\
(0.956)\end{array}$ \\
\hline CFO & $\begin{array}{l}-0.057 \\
(0.287)\end{array}$ & $\begin{array}{c}-0.008 \\
(0.658)\end{array}$ & $\begin{array}{l}-0.000 \\
(0.981)\end{array}$ & $\begin{array}{c}0.003 \\
(0.844)\end{array}$ \\
\hline LROA & $\begin{array}{l}-0.078 \\
(0.211)\end{array}$ & $\begin{array}{l}-0.055^{* *} \\
(0.043)\end{array}$ & $\begin{array}{c}-0.069^{* * *} \\
(0.009)\end{array}$ & $\begin{array}{l}-0.051^{*} \\
(0.068)\end{array}$ \\
\hline Year and industry $F E$ & Yes & Yes & Yes & Yes \\
\hline$N$ & 300 & 1042 & 909 & 875 \\
\hline $\operatorname{Adj} R^{2}$ & 0.263 & 0.260 & 0.295 & 0.298 \\
\hline
\end{tabular}

Notes: The table presents results of the regression Model 6 where we regress the market value of the IPO firm on the first day of listing divided by total assets (MTA) on signed abnormal accruals, foreignness and home institutions. Column (1) presents regression results for Model 6 for the subsample of foreign firms. Column (2) presents regression results for Model 6 for the full sample. Columns (3) and (4) present regression results for Model 6 for the subsamples of US IPOs and foreign IPOs from strong or weak institutions, respectively. $p$-values based on standard errors corrected for heteroskedasticity and clustering at the industry level are reported in parentheses below the coefficient estimates. ${ }^{* * * * * *}$ indicate significance at the two-tailed $10 \%, 5 \%$, and $1 \%$ levels, respectively. See the Appendix for variable definitions. 
Appendix: Variable Definitions

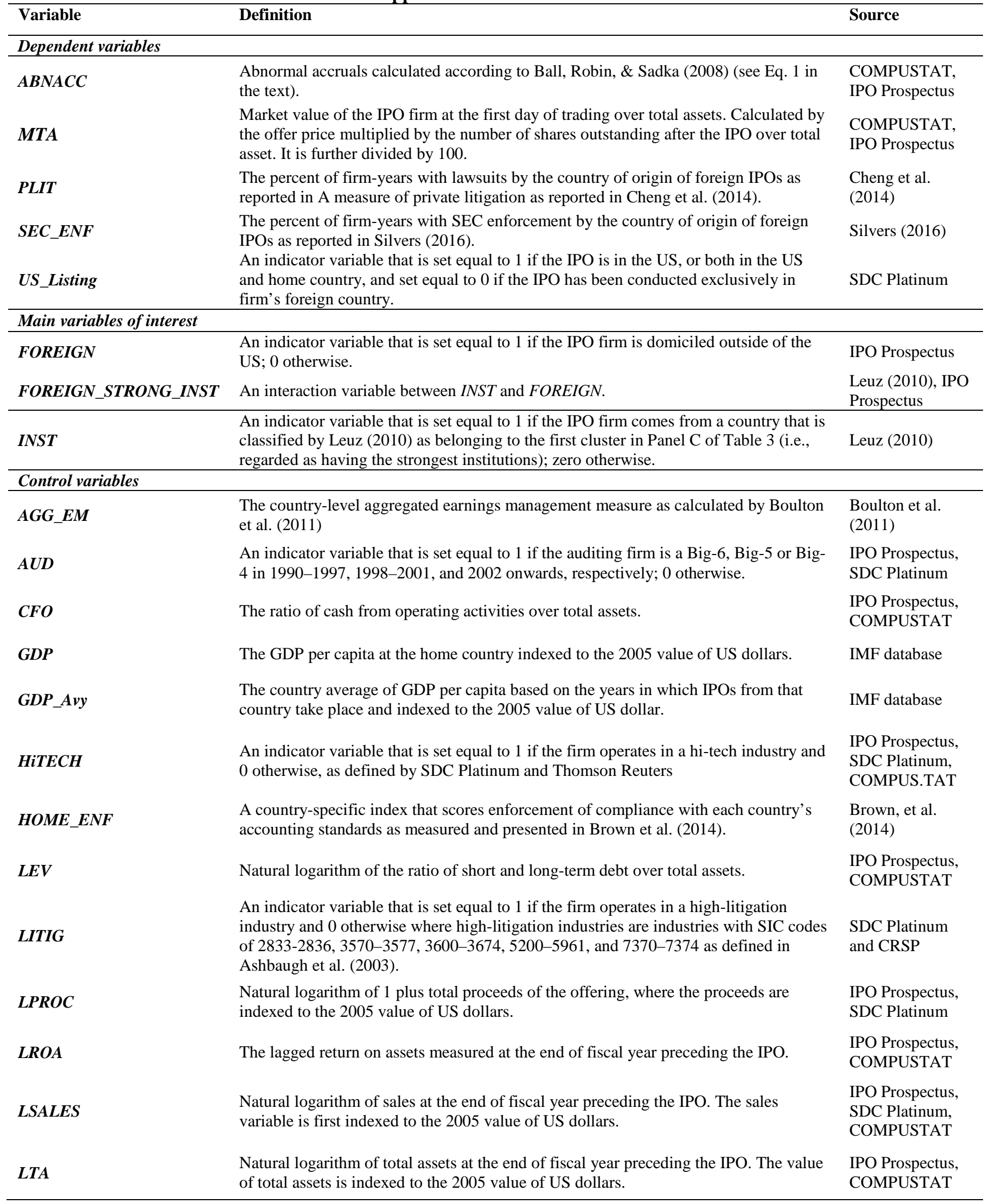


